Volume 5, Issue 1 (Winter 2013)

\title{
The Paintings in the Three Civic Guard Halls in Amsterdam, Written by G. Schaep, 1653
}

Tom van der Molen, translator

Recommended Citation:

G. Schaep, “The Paintings in the Three Civic Guard Halls in Amsterdam," trans. Tom van der Molen, JHNA 5:1 (Winter 2013) DOI:10.5092/jhna.2013.5.1.7

Available at https://jhna.org/articles/paintings-three-civic-guard-halls-amsterdam-written-by-gschaep-1653/

Published by Historians of Netherlandish Art: https://hnanews.org/

Republication Guidelines: https://jhna.org/republication-guidelines/

Notes: This PDF is provided for reference purposes only and may not contain all the functionality or features of the original, online publication. This is a revised PDF that may contain different page numbers from the previous version. Use electronic searching to locate passages. This PDF provides paragraph numbers as well as page numbers for citation purposes.

ISSN: 1949-9833 


\section{THE PAINTINGS IN THE THREE CIVIC GUARD HALLS IN AM- STERDAM, WRITTEN BY G. SCHAEP, 1653}

Tom van der Molen, translator

Translation of a new transcription ${ }^{1}$ of Gerrit Pietersz. Schaep's notes (1653) on paintings in the three civic guard halls of Amsterdam: the Handboogsdoelen (Longbow Archers Civic Guard Hall), the Voetboogsdoelen (Crossbow Archers Civic Guard Hall) and Kloveniersdoelen (Arquebusiers Civic Guard Hall), today in the Stadsarchief Amsterdam.

For more information on this document, see Tom van der Molen, "Introduction to the Translation of D. C. Meijer, Jr., "The Amsterdam Civic Guard Portraits within and outside the New Rijksmuseum" (De Amsterdamsche Schutters-stukken in en buiten het nieuwe Rijksmuseum)," JHNA 5:1 (2013). 10.5092/jhna.2013.5.1.7

\section{Record and list of the public paintings kept at the three civic guard halls: ${ }^{2}$ as I have found them, after my return to Amsterdam in February $1653 .{ }^{3}$}

\section{1: At the longbow archers civic guard hall [Handboogsdoelen $]^{4}$ (fig. 1)}

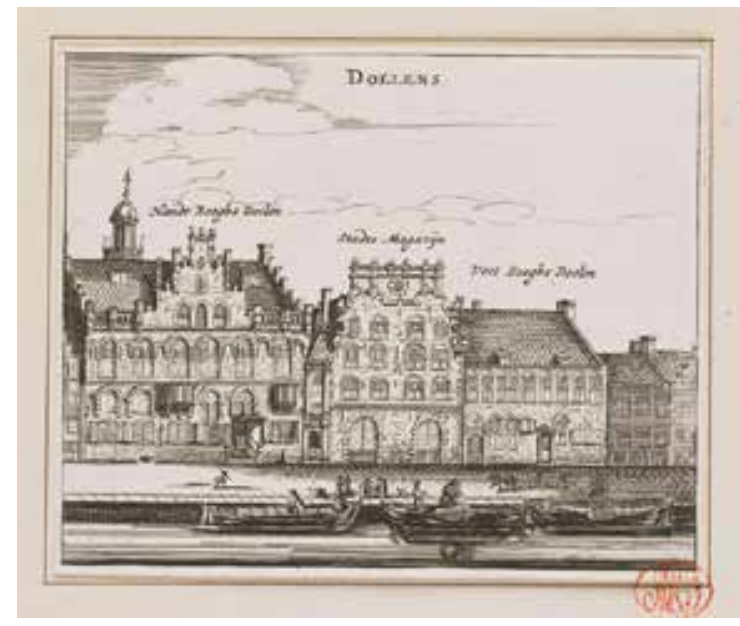

Fig. 1 Anonymous, The Longbow- and Crossbow- Civic Guard Halls and the City Arsenal, ca. 1606, etching, 113 x 140 mm, Rijksmuseum, Amsterdam, inv. no. RP-P-A0-1925-635-A

At the longbow civic guard hall: upstairs in the large room [grootte Camer], towards the side of the Lutheran church. 
Before the chimney, an old piece, done, as is mentioned at the bottom of the frame: 1531. [The guardsmen] are 2 high, and in the top row one with a music book

The 2 doors, that belong to this piece, on the sides of the previously mentioned chimney, but done 28 years later, namely Ao 1559 as is to be seen on each door, with half of this number on each door. On the side of the street on the top and bottom of the frame the following is written: "Het lustige rot van de Letter L. Capiteins gebod voldoen sij snel. 15=" [The joyous squad of the letter L. They quickly obey the captain's orders. 15=].

On the other side of the chimney, on the other door, is rhymed this: "Tweedrachtige spot en Toornicheyt fell. Keer van haer, God van Israel $=59$ " [Discordial ridicule and fierce wrath. Turn from her, God of Israel $=59] .^{5}$

[in the margin: $\gamma$ Ao 1529]

Still in the same large room. A piece opposite from where you come in through the door. Hanging lower, where on the side of the frame is written: "Trijn is hier komen wonen 1529" [Trijn has come to live here 1529]. These words are written around where an old woman is painted on the mentioned panel, she has a dish with apples. ${ }^{6}$

On the other side of the chimney, also low, is an old piece from the year 1558. [marked:] H

In which one with a sheet of music, in which these words: "Een man Een wijf" [A man A woman], on music notes. ${ }^{7}$

\section{[in the margin: $\varepsilon$ Ao 1623]}

Above those last two pieces are, on both sides of the chimney, a half of the piece in which Jacob Gerritsz Hoinck is captain to the side of the street and Pieter Hasselaer lieutenant to the side of the target range. From $1623 .^{8}$ (fig.2)

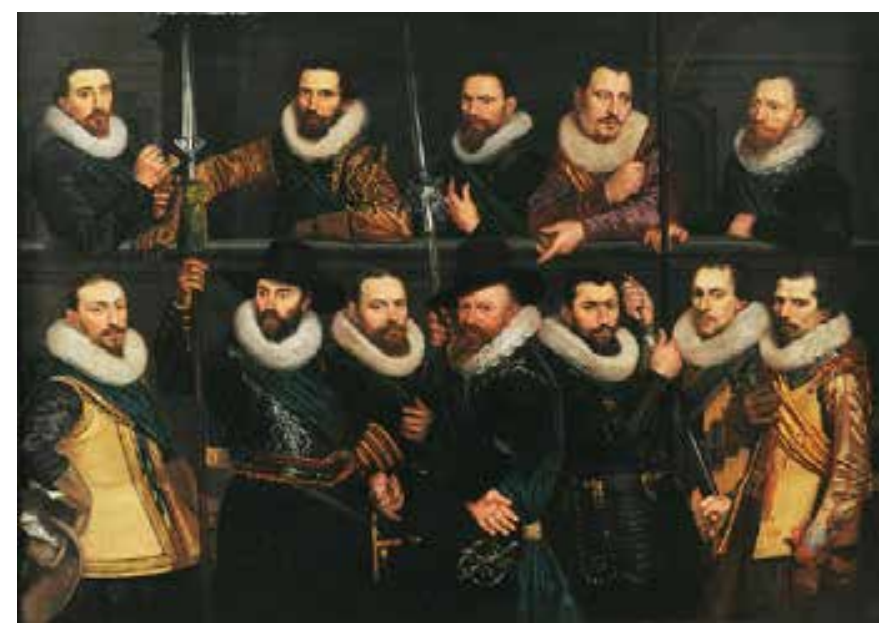

Fig. 2 Cornelis van der Voort, Company of Pieter Dirksz Hasselaer, 1623, oil on canvas, $184 \times 259 \mathrm{~cm}$. Amsterdam Museum, inv. no. SA 9909 
In the same room against the middle wall, above the door, in which the captain is and lieutenant ...... written on the frame $1604 .^{9}$

[in the margin: $\eta$ Ao 1604]

Ibidem next to it towards the side of the street, the scene in which ...... is captain and ...... lieutenant written on the frame $1604 .^{10}$

In the large hall

Before the chimney, [there is an] empty [spot], because the piece, that hung there until now, has been taken to the small room above the gate. In its place, the 4 governors, burgomaster Frans Banning Cock and the 3 aldermen Poll, Pater and Blaeu will have themselves painted and hung there. $^{11}$

[in the margin: $\theta$ Ao ....]

On the side of the chimney, towards the shooting range, is the piece in which... Poppen is captain and ...... lieutenant. They sit at an unset table. ${ }^{12}$

10 [in the margin: 1 Ao ....]

On the other side of the chimney, Geurt Dircksz van Beuningen is captain and lieutenant ...... This piece is painted by ... Tengnagel, afterwards deputy sheriff. ${ }^{13}$ (Fig. 3)

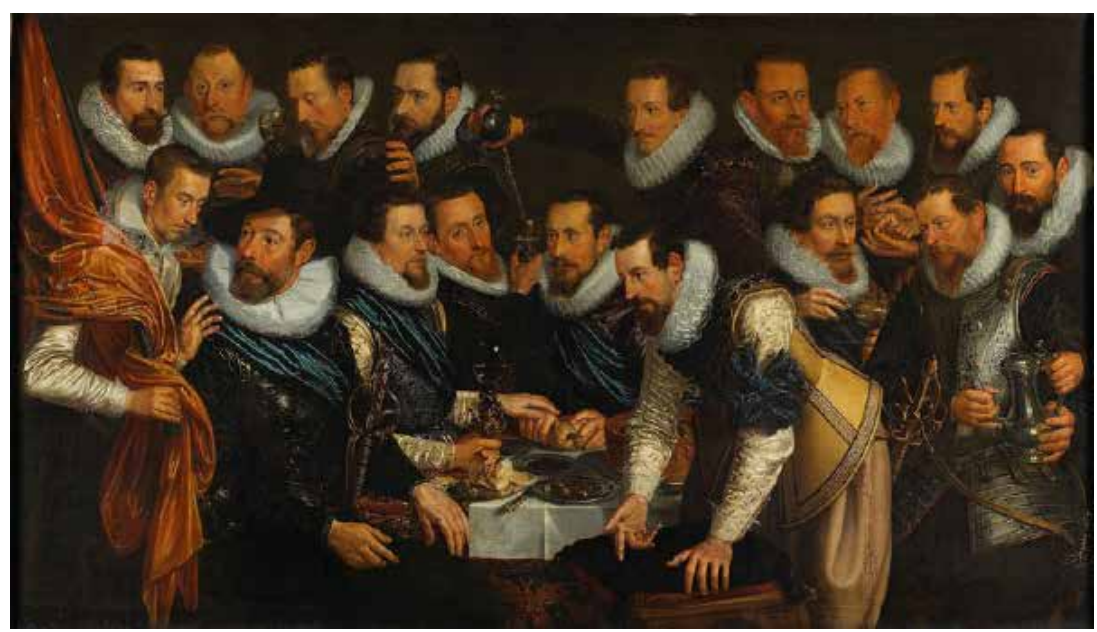

Fig. 3 Jan Tengnagel, Company of Captain Geurt van Beuningen and Lieutenant Pieter Hoefijzer, 1613, oil on canvas, $155 \times 264 \mathrm{~cm}$, Amsterdam Museum, inv. no. SA 7408

\section{1 [in the margin: $\kappa$ Ao 1585]}

Against the middle wall, towards the side of the street is the piece of 1585, being two [rows] high, painted by ... Barendsz. ${ }^{14}$

12 [in the margin: $\lambda$ Ao 1595]

Ibidem against the same middle wall, towards the side of the shooting range, a piece from 1595. As is written on the upper side of the frame, in the bottom side of the frame is written: Christianus de Conflans F. ${ }^{15}$

13 [in the margin: $\mu$ Ao 1535]

Ibidem above the door, an old piece with red and green robes. On the bottom part of the frame: 
Ao DNI. 1535. ${ }^{16}$

14 [in the margin: $v$ Ao ....]

In the large room above the hallway, is a piece in which about 8 or 10 young men are painted, with muskets among them ... Oetgens, who is cross-eyed, painted by ... Tengnagel, afterwards deputy sheriff. ${ }^{17}$

15 [in the margin: $\rho$ Ao 1533]

In the small room above the gate, between the chimney and the street, the piece has been hung, that used to be on the chimney of the large hall. painted in 1533. all of the depicted hold an arrow in their hands, in the middle is the king of the Parrot shooting ${ }^{18}$ with the scepter in his hand. ${ }^{19}$

16 [in the margin: $\sigma$ Ao 1650]

In the large room above the gate, the new piece in which alderman Jan van der Poll is Captain and his brother Gijsbert van der Poll Lieutenant. Painted by Jan Spilbergh. Ao $1650 .{ }^{20}$

17 [in the margin: $\tau$ Ao 1566]

In the front hall [In't voorhuijs].

Coming in on the right hand side, 2 pieces, but belonging together, of the year 1566 as is visible in the upper side and on the back of a chair. ${ }^{21}$

18 [in the margin: $v$ Ao 1586]

On the opposite side, a piece done by Dirck Barentsz, in which the Captain is Egbert Vinck, and Lieutenant ...... Ao 1586 On the side of the street. ${ }^{22}$

19 [in the margin: $\varphi$ Ao 1603]

Idem next to it, on the side of the shooting range, the piece in which the Captain is Pieter Adriaensz Raep, Lieutenant ... van der Hem, done in 1603 . $^{23}$

NB.

These governors have commissioned a sketch on paper of each piece, by ..... painter, for writing down all the names with the sketch, "ad perpetuam memoriam quod ad in posterum reperiri poterit." ${ }^{24}$

\section{Record and list of the public paintings at the crossbow archers civic guard hall (Voetboogsdoelen) as they were in February Ao 1653. ${ }^{25}$}

20 [in the margin: $\alpha$ Ao 1648]

In the old hall before the chimney, alderman Cornelis Witsen Captain, Jan Oetgens van Waveren, Lieutenant, painted Ao 1648 by Bartholomeus van der Helst. ${ }^{26}$

21 [in the margin: $\beta$ Ao 1645]

JHNA 5:1 (Winter 2013) 
Ibidem on the side towards the courtyard of the civic guard hall the piece by Captain Jacob Rogh, and Antonie de Lange painted by Claes Elias Ao $1645 .{ }^{27}$

22 [in the margin: $\gamma$ Ao 1579]

Ibidem above the door, Jan Huijdekooper the elder, Captain, and ..... painted Ao 1579. ${ }^{28}$

23 [in the margin: $\delta$ (in a later hand:) Ao 1650]

Ibidem against the middle wall, Captain Jan Huijdekooper the younger, and Frans van Waveren Lieutenant, painted Ao 1650 by Govert Flinck. ${ }^{29}$ (Fig.4)

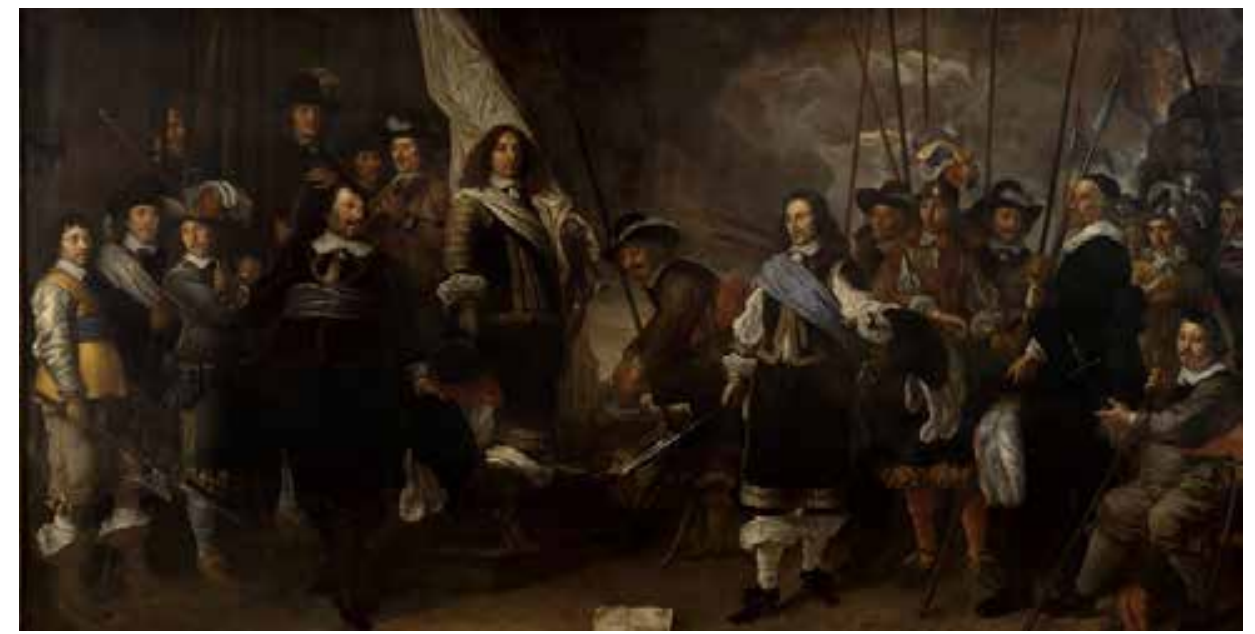

Fig. 4 Govert Flinck, Company of Captain Joan Huydecoper and Lieutenant Frans van Waveren Celebrating the Treaty of Münster, 1650, oil on canvas, $265 \times 513 \mathrm{~cm}$, Amsterdam Museum, inv. no. SA 7318

24 [in the margin: $\varepsilon$ Ao 1553]

Ibidem behind the piece that is in front of the chimney is the old piece [marked] A. of Ao 1552. In which the civic guardsmen wear the sign on the sleeve of their garments. ${ }^{30}$

25 [in the margin: $\zeta$ Ao 1625]

On the other room upstairs, called St. Joris [St. George], before the chimney, in which the alderman Albertus Coenradi is captain and Pieter Evertsz Hulft his Lieutenant. 1625. Painted by ... Vlack. $^{31}$

26 [in the margin: $\eta$ Ao 1618]

Ibidem above the middle wall, Captain Arent ten Grootenhuijs. lieutenant Nanning Florisz. Cloeck. Painted by Frans Barentsz. Ao $1618 .^{32}$

27 [in the margin: $\theta$ Ao 1623]

Ibidem on the side of the shooting range, 9 or 10 persons from the head till the feet being captain Abraham Boom, lieutenant Antonie Oetges which piece has been begun by ... Lastman, but because of his death afterwards finished by ... Nuland.

This company had been garrisoned outside the city in Zwolle. ${ }^{33}$ 
Ibidem on the side of the chimney, is an old piece signed C. $1555 .{ }^{34}$

29 [in the margin: $\kappa$ Ao 1564]

Ibidem and below the previous, the piece signed G. Ao 1564. Painted by Dirck Barentsz. ${ }^{35}$ (Fig.5)

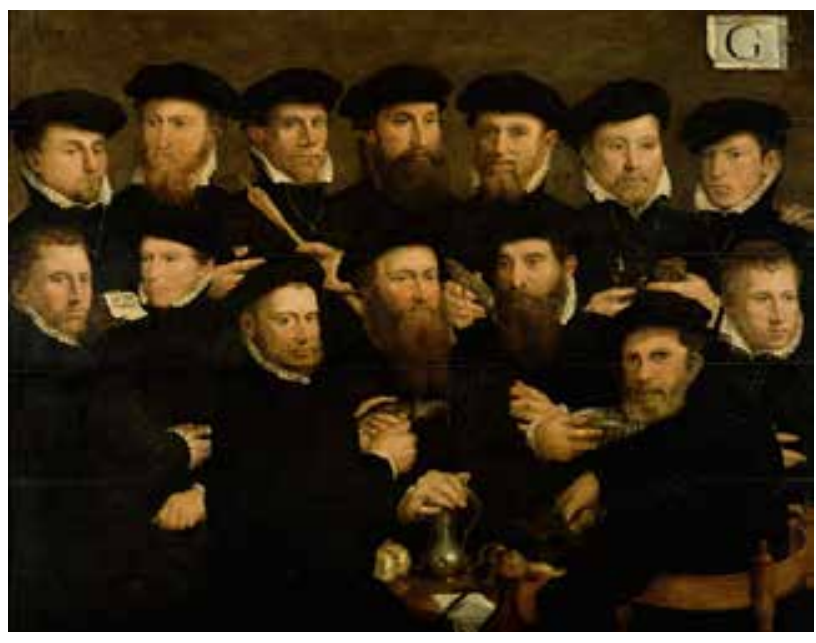

Fig. 5 Dirck Barendsz, Civic Guardsmen of Squad G, 1562, oil on panel, $142 \times 182 \mathrm{~cm}$, Amsterdam Museum, inv. no. SA 7287

[in the margin: $\lambda$ Ao 1628]

On the room called " $t$ ' Stick." Coming in from the right hand Captain Jacob Pietersz Hooghkamer, Lieutenant Pieter Jacobsz van Rijn painted Ao 1628 by ... Lyon. ${ }^{36}$ (Fig.6)

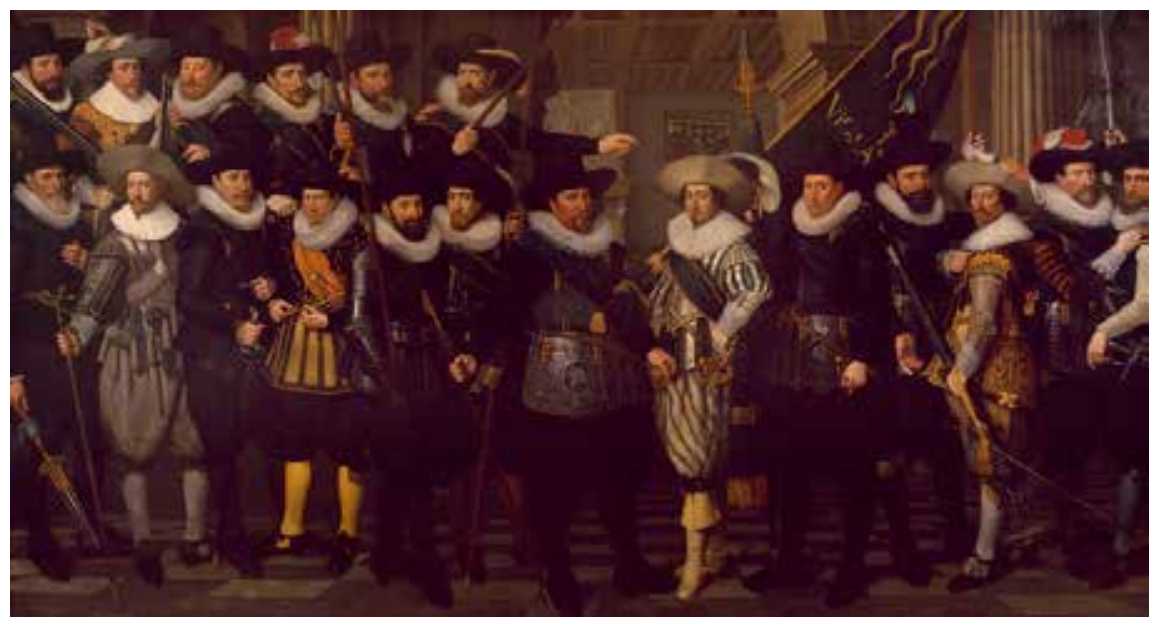

Fig. 6 Jacob Lyon, Company of Captain Jacob Pietersz Hooghkamer and Lieutenant Pieter Jacobsz van Rijn, 1628, oil on canvas, $254 \times 477.5 \mathrm{~cm}$, Amsterdam Museum, inv. no. SA 998

31 [in the margin: $\boldsymbol{\mu}$ Ao 16..]

Ibidem before the chimney, Captain Mathijs Willemsz. Raephorst and Lieutenant Hendric Lourisz bookseller "op t'water" [on the Damrak], painted by Claes Elias Ao.... ${ }^{37}$

32 [in the margin: $v$ Ao 16..]

Ibidem next to the chimney. Captain Jacob Backer, and Jacob Rogh lieutenant. Painted by Claes Elias, Ao 16 .... ${ }^{38}$ 
On the room called No 4 an old piece of Ao 1554 E. ${ }^{39}$

34 [in the margin: $\sigma$ 1559]

Ibidem an old piece of Ao 1559, signed B. ${ }^{40}$

35 [in the margin: $\tau$ 1564]

In the hallway opposite. A piece signed $\mathrm{K}$ on the top part of the frame Ao $1564 .{ }^{41}$

36 [in the margin: $v$ 1533]

In the room No 5. An old piece sitting at the table where a roasted heron has been drawn lying in the dish signed (alij D. dicunt) 1533 C.N. N.

ubi SB. in Flore aetatis, vide in senectute alibi supra. ${ }^{42}$ (Fig.7)

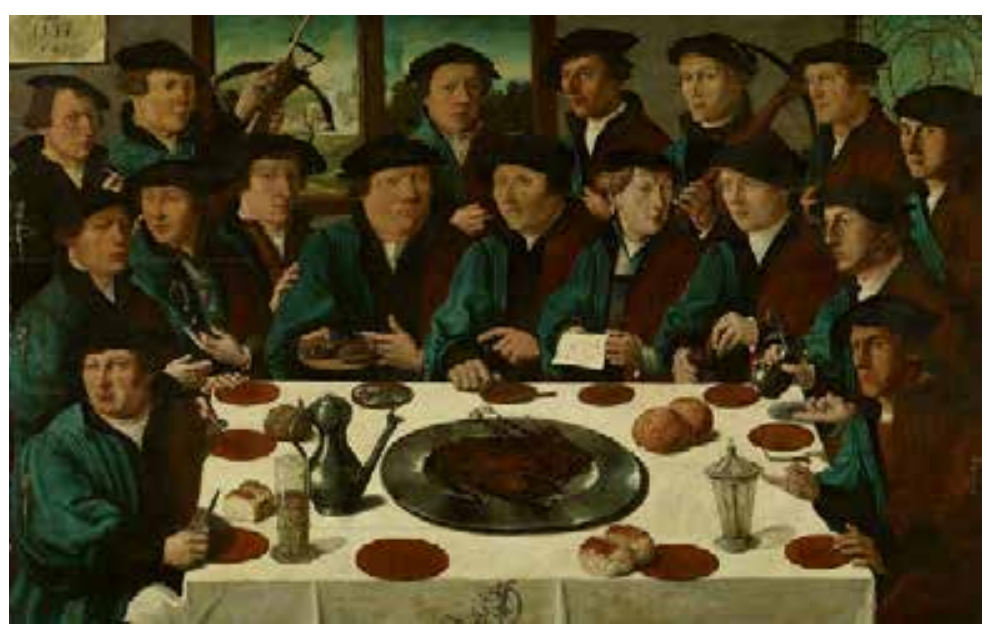

Fig. 7 Cornelis Anthonisz, Meal of a Squad of Civic Guardsmen of the St. George Militia Guild, 1533, oil on panel, 130 x $206.5 \mathrm{~cm}$, Amsterdam Museum, inv. no. SA 7279

\section{7 [in the margin: $\varphi$ 1588]}

In the room No 6. A piece from 15 A 88. In this one is Sheriff Verdoel. ${ }^{43}$

38 [in the margin: $\chi$ 1553]

Ibidem. Another old piece signed A.D. $1553 .{ }^{44}$

39 [in the margin: $\psi$ 1555]

Ibidem. Another one signed (G credo) Ao 1555, among which there is one that has on a letter pro sijmbolo ex animo omnia. ${ }^{45}$

40 [in the margin: $\omega$ 1551]

On the landing near the stairs going down, is written on the frame of a piece Anno Domini $1551 .{ }^{46}$ 
Downstairs, the new hall, opposite the windows, captain Jacobs Sijmonsz de Vries, Lieutenant Dirck Graef. Ao 1633 painted by Thomas Keijser. ${ }^{47}$

\section{[in the margin: $\beta \beta$ 1637]}

Ibidem opposite the chimney, Captain Reijnier Reael, lieutenant Cornelis Michielsz Blau, Ao 1637. Started bij Francois Hals, and afterwards finished by Codde. ${ }^{48}$

43 [in the margin: $\gamma \gamma$ 1588]

In the front house against the fire place, ... Rosencrants captain and lieutenant ... Pau Ao 1588 painted by Ketel. ${ }^{49}$

44 [in the margin: $\delta \delta$ 1599]

Ibidem opposite from that, Jillis Jansz Valckenier captain Pieter Bas lieutenant Ao 1599 done by Pieter IJsaxsz who afterwards became a resident in the Øresund..$^{50}$ (Fig.8)

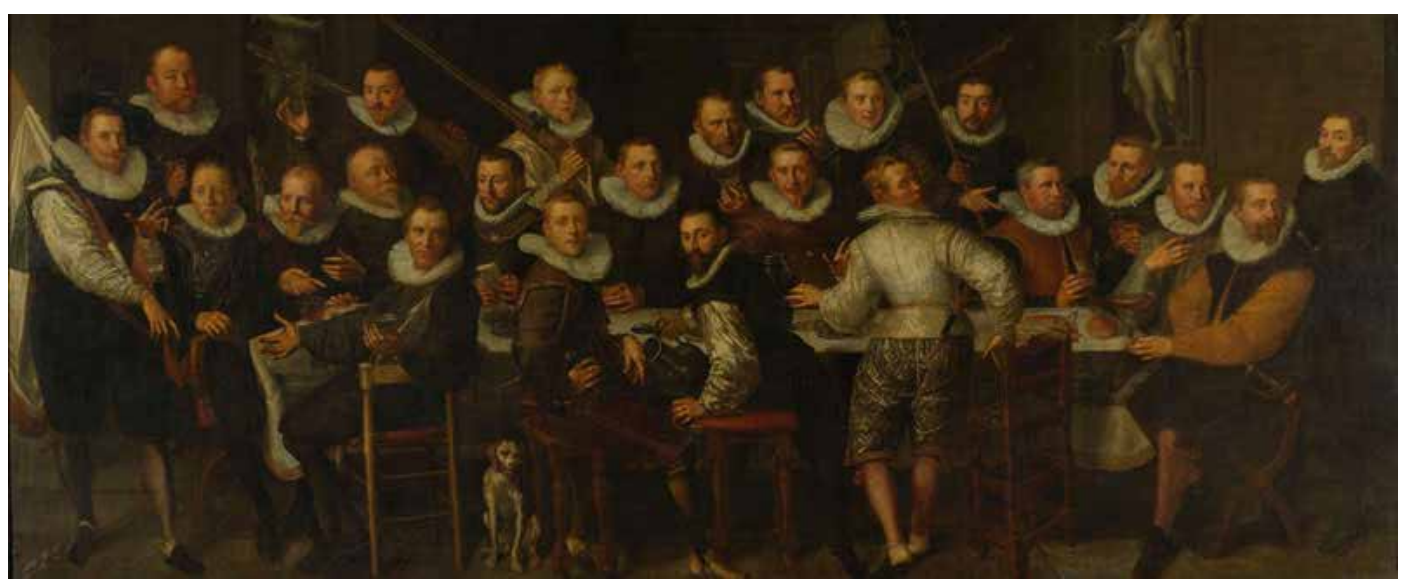

Fig. 8 Pieter Isaacsz, Company of Captain Gillis Jansz Valckenier and Lieutenant Pieter Jacobsz Bas, 1599, oil on canvas, 218 x $526 \mathrm{~cm}$, Rijksmuseum, Amsterdam, inv.no. SK-C-455, on loan from the city of Amsterdam (SA 7339)

\section{Record and list of the paintings in the Arquebusiers civic guard hall (Klove- niersdoelen)(Fig.9)}

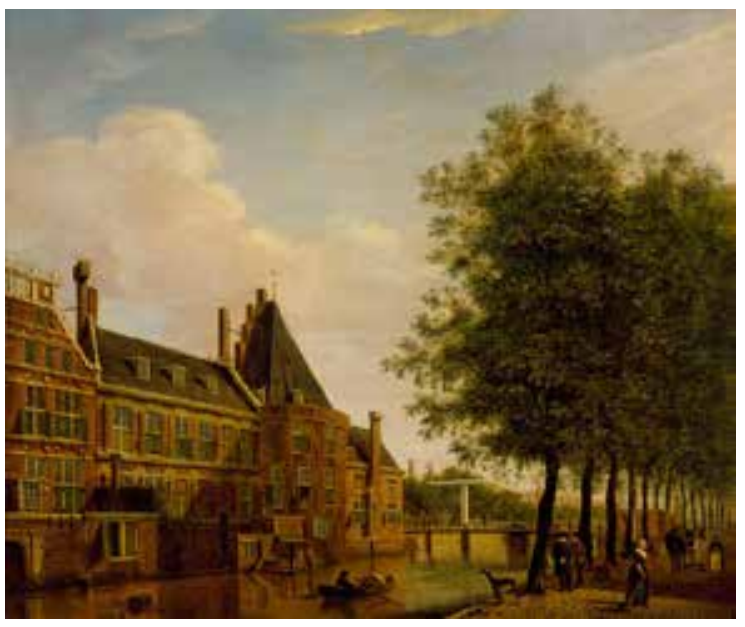

Fig. 9 Jan (I) Ekels (1724-1781), Arquebusiers Civic Guard Hall from the Amstel River, 1775, oil on canvas, $48.5 \times 57 \mathrm{~cm}$, Amsterdam Museum, inv. no. SA 8422 
[1] Before the chimney in the great hall, the 4 governors, Burgomaster Albertus Conradi, Pieter Reael, receiver of the common means of Holland, Jan Claesz Vlooswijck, and Jacob Willkes. Painted by Govert Flinck. ${ }^{52}$ (Fig.10)

[2] Ibidem on the right hand side of the chimney, towards the Amstel, captain Cornelis Bicker, heer van Swieten, Lieutenant Frederick van Banchem the notary painted by... Sandraert. Ao $1640 .^{53}$ (Fig.11)

[3] Ibidem to the left hand side Albert Bas captain, Lucas Conijn Lieutenant done by Govert Flinck. 1645. ${ }^{54}$ (Fig.12)

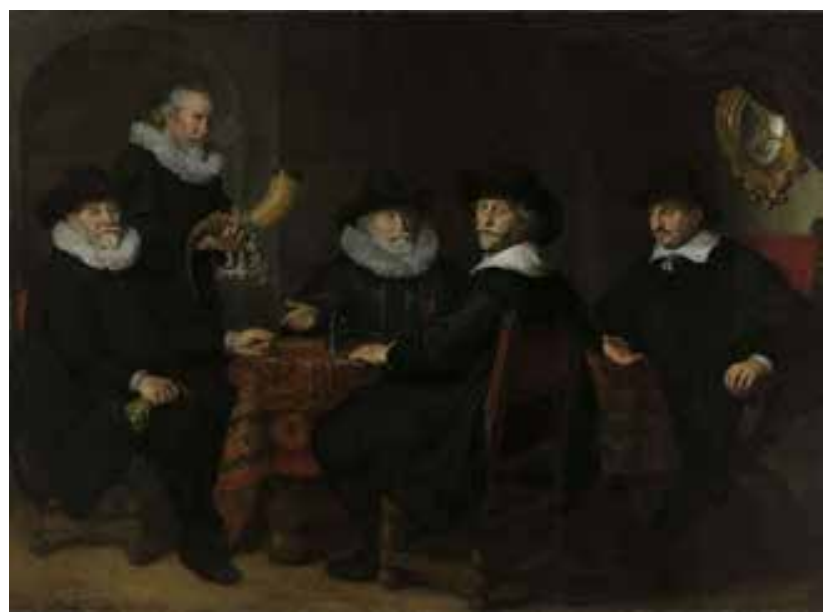

Fig. 10 Govert Flinck, Governors of the Kloveniersdoelen, 1642, oil on canvas, $203 \times 278 \mathrm{~cm}$, Rijksmuseum, Amsterdam, inv. no. SK-C-370, on loan from the city of Amsterdam (SA 7316)

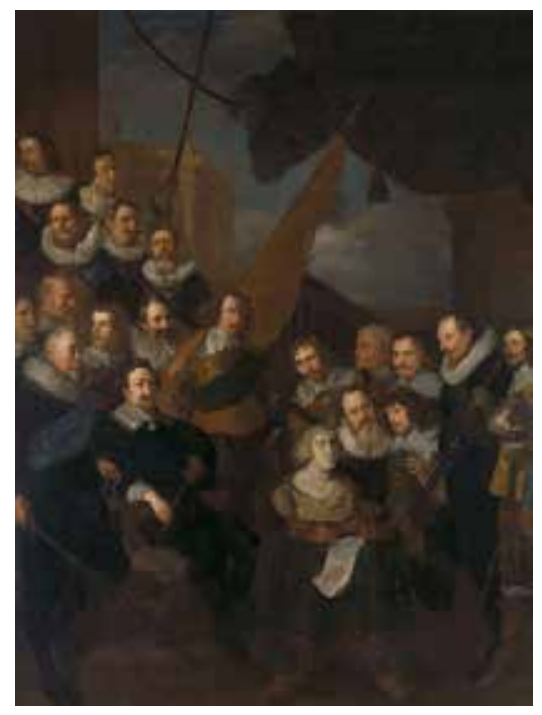

Fig. 11 Joachim von Sandrart, Company of Cornelis Bicker and Lieutenant Frederick van Banchem, 1638-40, oil on canvas, $343 \times 258 \mathrm{~cm}$, Rijksmuseum, Amsterdam, inv. no. SK-C-393, on loan from the city of Amsterdam (SA 7399)

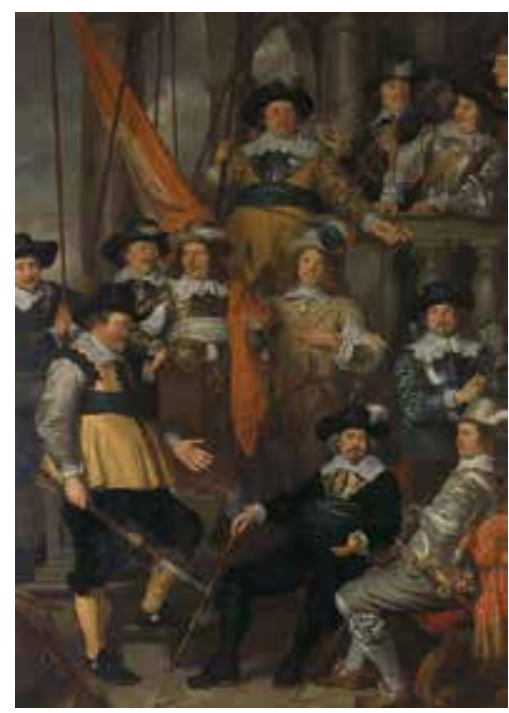

Fig. 12 Govert Flinck, Company of Albert Bas and Lieutenant Lucas Conijn, 1645, oil on canvas, $347 \times 244$ cm, Rijksmuseum, Amsterdam, inv. no. SK-C-371, on Ioan from the city of Amsterdam (SA 7317)

[4] Ibidem following next to that Frans Banning Cock captain and Willem van Ruijtenburg lieutenant painted by Rembrand Ao $1642 .{ }^{55}$ 
[5] Ibidem following as before Jan Claesz Vlooswijck captain, Gerrit Hudde lieutenant done Ao .... by ...... ${ }^{56}$

[6] Ibidem Cornelis Graef. captain. Hendric Lourisz bookseller, painted by JABacker [JAB in ligature] Ao 1642..$^{57}$

[7] Ibidem before the chimney near the entrance. Roelof Bicker. captain. Jan Michielsz Blau. Lieutenant. Ao 1643. Done by Bartholomeus van der Helst. ${ }^{58}$

[8] In the front of the front house, above the stairs going up to the large hall

Allaert Cloeck alderman. captain. Lucas Jacobsz Rotgans lieutenant. Ao ... done by ... Keijser. ${ }^{59}$ (Fig.13)

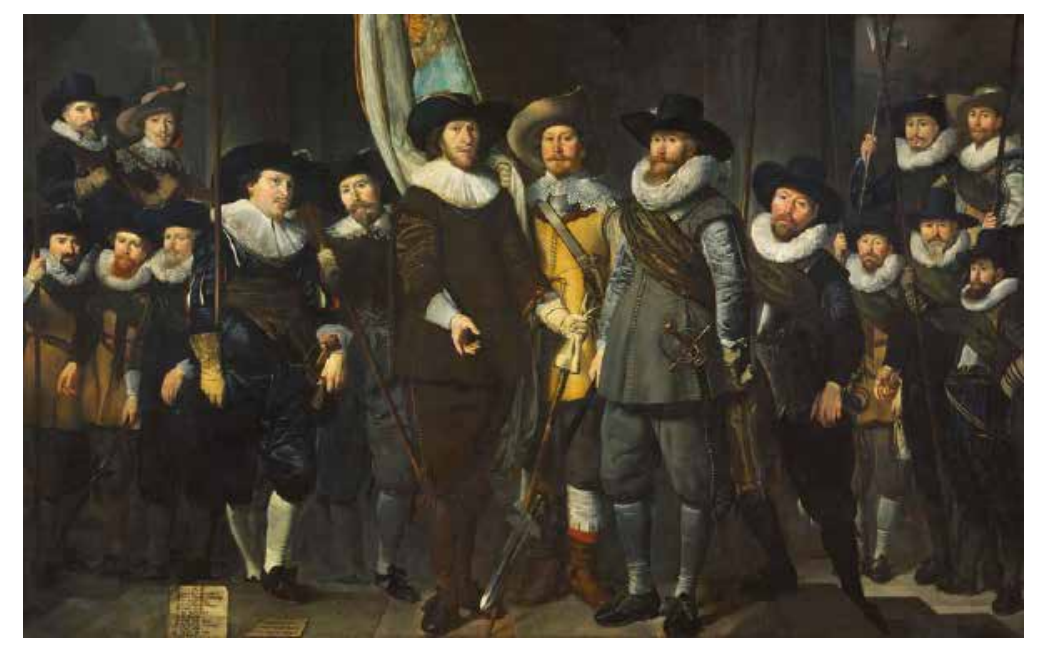

Fig. 13 Thomas de Keyser, Company of Captain Allaert Cloeck and Lieutenant Lucas Jacobsz Rotgans, 1632, oil on canvas, $220 \times 351 \mathrm{~cm}$, Rijksmuseum, Amsterdam, inv.no. SK-C-381, on loan from the city of Amsterdam (SA 7353)

[9] Ibidem in the front house, following the previous. Dirck Theulingh captain and Adriaan Pietersz Raep. lieutenant done Ao 1639 by Claes Elias. ${ }^{60}$

[10] Ibidem in the front house opposite the door leading in from the street. The old Pieter Dirxsz Hasselaer. captain. Jan Gerritsz Hooft. lieutenant. ${ }^{61}$

[11] Ibidem against the wall to the Conings-kamer (King-room), the old Jacob Cappit. captain ..... lieutenant painted by Dirck Barentsz. ${ }^{62}$

[12] Ibidem against the wall to the Prince Camer (Prince room) Dirck Jacobsz Rosecrans. captain ... Ruysch. lieutenant. Done by Ketel. ${ }^{63}$

\section{7 [in the margin: 12 pieces in all]}

48 [in the margin: 6 pieces on the 2 rooms in the front house going out]

Next to the front house in the Conings-kamer (King-room), on the side of the water

[13] Before the chimney, an old piece with 2 doors signed M Ao $1559 .{ }^{64}$

[14] On the wall opposite the windows. Alderman Spiegel. captain. Jacob Servaes lieutenant. 1638. Ao 1638 painted by JABacker [JAB in ligature] ${ }^{65}$

[15] In the same room above the chimney. An old piece, by Dirck Barentsz geschildert. Ao .... ${ }^{66}$

[16] On the Prince-kamer [Prince room], next to the front house towards the street

Before the chimney an old piece signed F Ao .... ${ }^{67}$ (Fig. 14) 
[17] Ibidem a piece in which Jan de Bisschop is captain and Pieter Egbertsz Vinck ensign. ${ }^{68}$ (Fig. 15)

[18] Ibidem another old piece. ${ }^{69}$

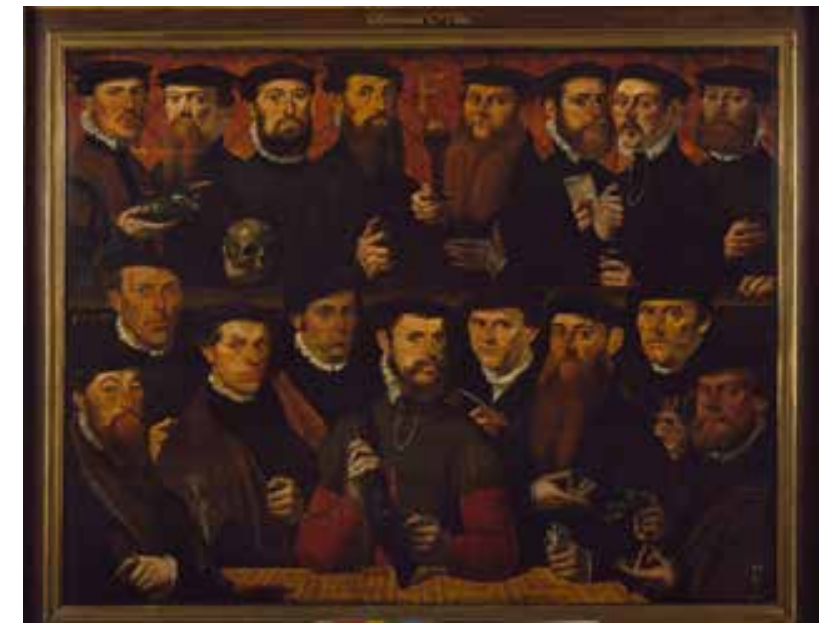

Fig. 14 Master of the Antwerp Family Portrait, Civic Guardsmen of Squad F, 1557, oil on panel, $133 \times 169.5 \mathrm{~cm}$, Amsterdam Museum, inv. no. SA 7344

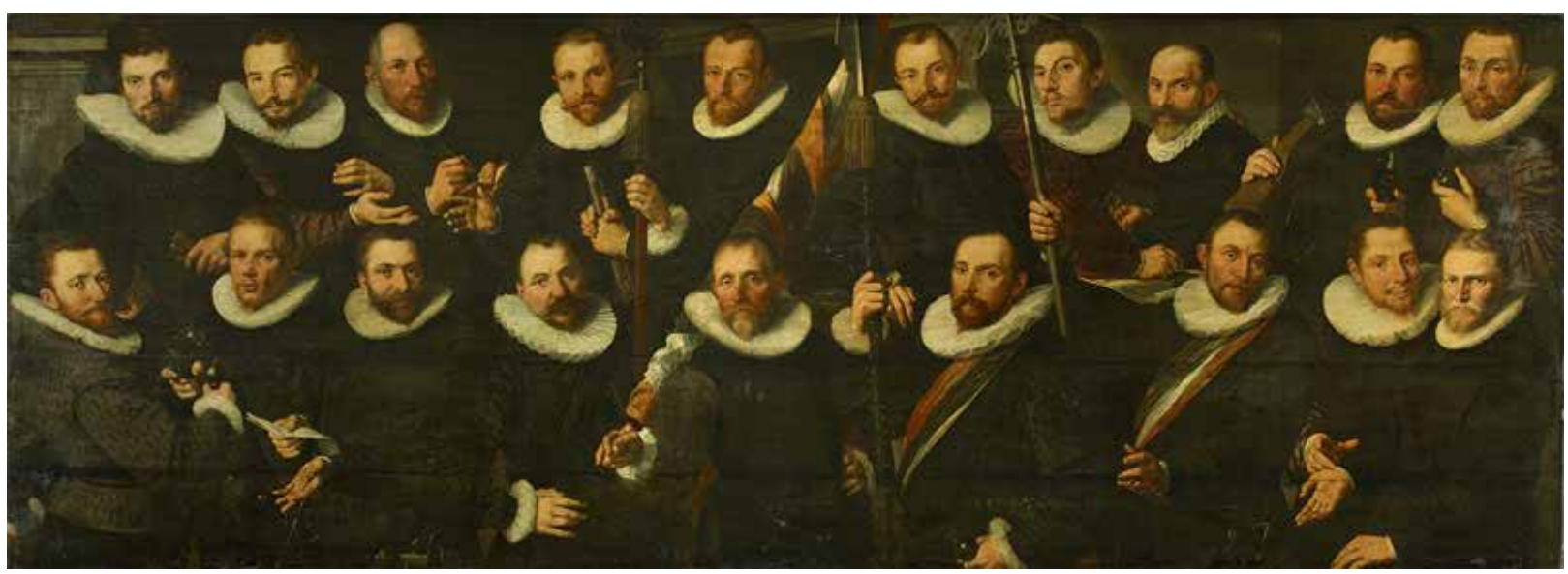

Fig. 15 Aert Pietersz, Company of Captain Jan de Bisschop and Lieutenant Pieter Egbertsz Vinck, 1599, oil on panel, $133 \times 362 \mathrm{~cm}$, Amsterdam Museum, inv. no. SA 7386

[in the margin: at $\mathbf{t}^{\prime}$ haertgen: 7]

In the room called het Haertgen

[19]A piece in which there are only 3 persons, among which the one with the cut doublet is said to be the colonel Ruijghaver.

[20] Ibidem above the door, coming from downstairs, an old piece with yellow and green vests. Of Ao ....

[21] Ibidem Jacob Gerritsz Hoing captain, .... Appelman lieutenant, Ao .... ${ }^{70}$

[22] Ibidem above t' Lict-du-camp. An old piece signed K.

[23] Ibidem another old piece, signed B Ao 1556. ${ }^{71}$

[24] Ibidem the piece with the XVII persons in plain armor. Ao $1531 .^{72}$

[25] Ibidem another long narrow piece with few persons. 
In the great Heere-kamer. Being next to the bridge [26] Above the door, Jonas Witsen Captain. Volckert Overlander lieutenant painted by Cornelis vander Hoogh. ${ }^{73}$

[27] Ibidem Jacob Gerritsz Hoing captain. Nanning Florisz Cloeck lieutenant Ao 1616 painted... ${ }^{74}$ Fig.16)

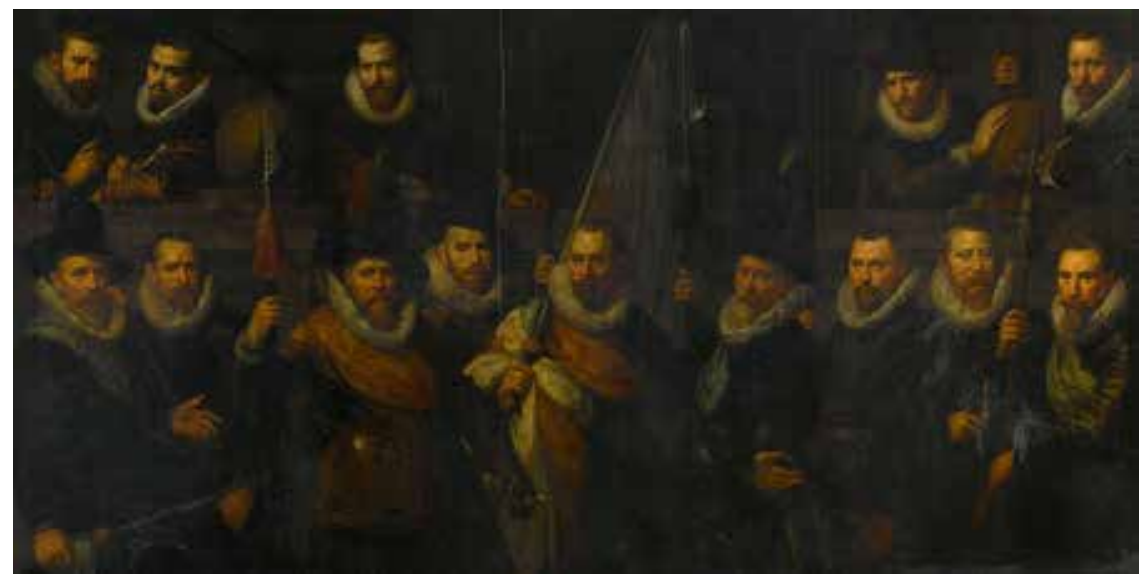

Fig. 16 Paulus Moreelse, Company of Captain Jacob Hoynck and Lieutenant Nanning Cloeck, 1616, oil on canvas, 169 × $333 \mathrm{~cm}$, Rijksmuseum, Amsterdam, inv. no. SK-C-623, on loan from the city of Amsterdam (SA 7373)

[28] Ibidem Albert Jonckein. captain. ...... lieutenant. painted Ao 1606. ${ }^{75}$

[29] Ibidem before the chimney, some civic guardsmen with their guns [doelroers]. ${ }^{76}$

51 [in the margin: 17 pieces both large and small, old and modern]

In the vestibule, or the doorway to the Heere Camer mentioned above.

52 [in the margin: 1 ]

[30] An old piece. In which my great grandfather Jacob Schaap Pietersz appears in the foreground. But the painting is becoming unrecognizable because of the flaking. ${ }^{77}$ In the bastion.

53 [in the margin: 5 ]

[31] A piece above the door. ${ }^{78}$

[32] Idem before the chimney. ${ }^{79}$

[33] Ibidem in corner. 2 pieces joined together. Signed E. $1561 .^{80}$ (Fig.17)

[34] Ibidem a piece painted by Dirck Barentsz. Called the Pos-eters. ${ }^{81}$

[35] Ibidem another piece of 8 persons. ${ }^{82}$

In the schutterskamer (civic guardsroom).

54 [in the margin: 2 ]

[36+37] 2 pieces both of ... civic guardsmen with their guns [doelroers], modern.

In the kleine Heerekamer. 


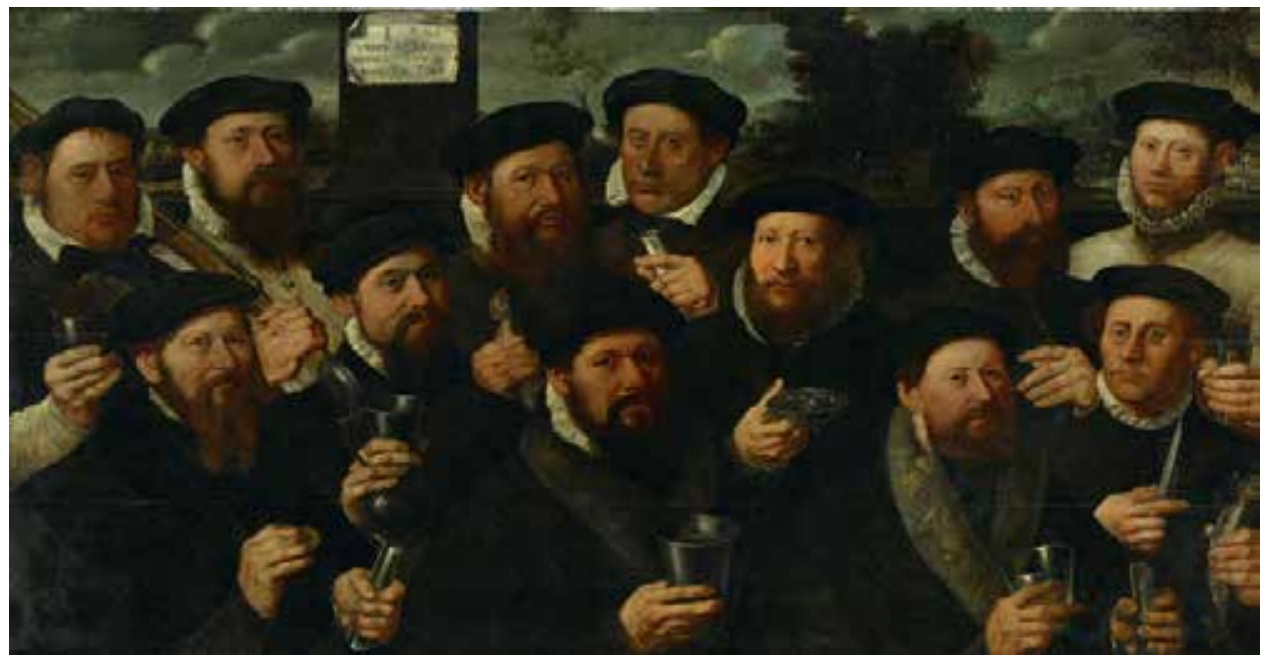

Fig. 17 Dirk Jacobsz, Twelve Civic Guardsmen of Squad E, 1563, oil on panel, $92.5 \times 178$ cm, Amsterdam Museum, inv. no. SA 7342

[38] An old piece, with yellow vests. Of Ao $1534 .{ }^{83}$

[39] Ibidem Another old piece with two doors. Of Ao 1529. ${ }^{84}$

[in the margin: 10 pieces $+17+12=39$ ]

\section{List of Illustrations}

Fig. 1 Anonymous, The Longbow- and Crossbow-Civic Guard Halls and the City Arsenal, ca. 1606, etching, 113 x 140 mm, Rijksmuseum, Amsterdam, inv. no. RP-P-AO-1925-635-A

Fig. 2 Cornelis van der Voort, Company of Pieter Dirksz Hasselaer, 1623, oil on canvas, 184 x 259 cm. Amsterdam Museum, inv. no. SA 9909

Fig. 3 Jan Tengnagel, Company of Captain Geurt van Beuningen and Lieutenant Pieter Hoefizer, 1613, oil on canvas, 155 x $264 \mathrm{~cm}$, Amsterdam Museum, inv. no. SA 7408

Fig. 4 Govert Flinck, Company of Captain Joan Huydecoper and Lieutenant Frans van Waveren Celebrating the Treaty of Münster, 1650, oil on canvas, 265 x $513 \mathrm{~cm}$, Amsterdam Museum, inv. no. SA 7318

Fig. 5 Dirck Barendsz, Civic Guardsmen of Squad G, 1562, oil on panel, 142 x $182 \mathrm{~cm}$, Amsterdam Museum, inv. no. SA 7287

Fig. 6 Jacob Lyon, Company of Captain Jacob Pietersz Hooghkamer and Lieutenant Pieter Jacobsz van Rijn, 1628, oil on canvas, 254 x 477.5 cm, Amsterdam Museum, inv. no. SA 998

Fig. 7 Cornelis Anthonisz, Meal of a Squad of Civic Guardsmen of the St. George Militia Guild, 1533, oil on panel, 130 x $206.5 \mathrm{~cm}$, Amsterdam Museum, inv. no. SA 7279 
Fig. 8 Pieter Isaacsz, Company of Captain Gillis Jansz Valckenier and Lieutenant Pieter Jacobsz Bas, 1599, oil on canvas, 218 x $526 \mathrm{~cm}$, Rijksmuseum, Amsterdam, inv.no. SK-C-455, on loan from the city of Amsterdam (SA 7339)

Fig. 9 Jan (I) Ekels (1724-1781), Musketeers Civic Guard Hall from the Amstel River, 1775, oil on canvas, 48.5 x $57 \mathrm{~cm}$, Amsterdam Museum, inv. no. SA 8422

Figs. 10-12

The paintings above and to the sides of the chimney in the great hall of the Arquebusierss civic guard hall (Kloveniersdoelen).

Fig. 10 Govert Flinck, Governors of the Kloveniersdoelen, 1642, oil on canvas, $203 \times 278 \mathrm{~cm}$, Rijksmuseum, Amsterdam, inv. no. SK-C-370, on loan from the city of Amsterdam (SA 7316)

Fig. 11 Joachim von Sandrart, Company of Cornelis Bicker and Lieutenant Frederick van Banchem, 1638-40, oil on canvas, 343 x 258 cm, Rijksmuseum, Amsterdam, inv. no. SK-C-393, on loan from the city of Amsterdam (SA 7399)

Fig. 12 Govert Flinck, Company of Albert Bas and Lieutenant Lucas Conijn, 1645, oil on canvas, 347 x $244 \mathrm{~cm}$, Rijksmuseum, Amsterdam, inv. no. SK-C-371, on loan from the city of Amsterdam (SA 7317)

Fig. 13 Thomas de Keyser, Company of Captain Allaert Cloeck and Lieutenant Lucas Jacobsz Rotgans, 1632, oil on canvas, 220 x 351 cm, Rijksmuseum, Amsterdam, inv.no. SK-C-381, on loan from the city of Amsterdam (SA 7353)

Fig. 14 Master of the Antwerp Family Portrait, Civic Guardsmen of Squad F, 1557, oil on panel, 133 x $169.5 \mathrm{~cm}$, Amsterdam Museum, inv. no. SA 7344

Fig. 15 Aert Pietersz, Company of Captain Jan de Bisschop and Lieutenant Pieter Egbertsz Vinck, 1599, oil on panel, 133 x $362 \mathrm{~cm}$, Amsterdam Museum, inv. no. SA 7386

Fig. 16 Paulus Moreelse, Company of Captain Jacob Hoynck and Lieutenant Nanning Cloeck, 1616, oil on canvas, 169 x $333 \mathrm{~cm}$, Rijksmuseum, Amsterdam, inv. no. SK-C-623, on loan from the city of Amsterdam (SA 7373)

Fig. 17 Dirk Jacobsz, Twelve Civic Guardsmen of Squad E, 1563, oil on panel, $92.5 \times 178 \mathrm{~cm}$, Amsterdam Museum, inv. no. SA 7342

\section{Bibliography \\ Primary Archival Sources}

SAA 5059. Collectie Stadsarchief Amsterdam: Handschriften, nos. 41-44; "Handschriften van Gerrit Pietersz. Schaep betreffende de geschiedenis van Amsterdam, ongedateerd" [1653] 
MS Egerton. Arms, in colors, of the Masters of the Hand-bow Company of Amsterdam, 1477-1659: -Portraits and arms of members of the same Company, for the same period;. Large oblong Quarto. British Library, Bibl. Eg. 983.

Beudeker, Christoffel. Oudheden van Amstelredamme, met aanteekeningen opgehelderd, meerendeels door Abraham Rademaker getekent, benevens een korte beschrijvinge van de oude Schutters Doelen derzelver stad / uit liefhebberij vergaderd en beschreven door Christoffel Beudeker. [No date] Library of the Amsterdam City Archives.

\section{Primary Printed Sources}

Dyk, Jan van. Kunst en Historiekundige beschryving en aanmerkingen over alle de schilderyen op het Stadhuis te Amsterdam. Amsterdam: Yver, 1758. http://books.google.nl/books?id=UMA9AAAAcAAJ\&hl=nl\&pg=PP11\#v=onepage\&q\&f=false

Mander, Karel van. Het Schilderboeck. Haarlem, 1604. http://dbnl.org/tekst/mand001schi01_01/

[Translations of Van Mander's quotes are from Miedema, Hessel. Karel van Mander: The Lives of the Illustrious Netherlandish and German Painters. Doornspijk, 1994-99.]

\section{Secondary Printed Sources}

Adams, Ann Jensen. "Civic Guard Portraits: Private Interests and the Public Sphere," In Beeld en Zelfbeeld in de Nederlandse Kunst, 1550-1750 / Image and Self Image in Netherlandish Art, 1550-1750. Edited by Reindert Falkenburg, Jan de Jong, Herman Roodenburg, and Frits Scholten. Nederlands Kunsthistorisch Jaarboek 46 (1995): 168-97.

Bauch, Kurt. Jakob Adriaensz Backer: Ein Rembrandtschüler aus Friesland. Berlin: G.Grote, 1926.

Bontemantel, Hans. De regeeringe van Amsterdam, soo in 't civiel als crimineel en militaire (16531672). Edited by G. W. Kernkamp. The Hague: Nijhof, 1897. http://www.dbnl.org/titels/titel. php?id=bont014rege01)

Dudok van Heel, S. A. C. “'The Night Watch' and the Entry of Marie de'Medici: A New Interpretation of the Original Place and Significance of the Painting." Rijksmuseum Bulletin 57, no. 1 (2009): $4-41$.

Gent, Judith van. “Dit in mijn stamboek te leggen': het dossier van Nicolaes Witsen in Brielle." Face Book: studies on Dutch and Flemish Portraiture of the 16th-18th Centuries: p. 451-462.

Haverkamp Begemann, Egbert. Rembrandt: The Nightwatch. Princeton, N.J.: Princeton University Press, 1982.

Mac Laren, Neil. The Dutch School, 1600-1900. Revised and expanded by Christopher Brown. London: National Gallery, 1991. 
Martin, Wilhelm. “Backer's Korporaalschap uit den Kloveniersdoelen te Amsterdam.” Oud Holland 50 (1933): 220-24. http://dx.doi.org/10.1163/187501733X00294

Scheltema, Pieter. Historische beschrijving der schilderijen van het stadhuis te Amsterdam. Amsterdam: Stadsdrukkerij, 1879.

Scheltema, Pieter. "De schilderijen in de drie doelens te Amsterdam, beschreven door G. Schaep, 1653." In Aemstel's oudheid of gedenkwaardigheden van Amsterdam, vol. 7 (1885), 121-41. http://dbnl.org/arch/sche078aems07_01/pag/sche078aems07_01.pdf

Schwartz, Gary. The Night Watch. Amsterdam/Zwolle: Rijksmuseum/Waanders, 2002.

Six, Jan, and W. Del Court. "De Amsterdamsche Schutterstukken.” Oud Holland 21 (1903): 65-80. http://dx.doi.org/10.1163/187501703X00071

Six, Jan. “De schilderijen in den Handboogsdoelen.” Oud Holland 15 (1897): 129-38. http://dx. doi.org/10.1163/187501797X00113

Six, Jan. “Dirk Jacobsz.: Twee Amsterdamsche Schutterstukken te St. Petersburg." Oud Holland 13 (1895): 91-111. http://dx.doi.org/10.1163/187501795X00052

\section{Addendum - New Transcription of the Document}

Memorie en[de] lijste van [de] publ[ieke] schilderijen op de 3 doelens bewaert worden[de]: soo als ick die gevonden hebbe, na mijn wederkomste tot Aemst[eldam] in februar[ij] 1653.

\section{1: Op de Hand-Boogs-Doelen}

In [de] Hantboogs doelen: boven op de grootte Camer, na de sijde van [de] Lutersche kerck.

\section{[in kantlijn a Ao 1531 ende $\beta$ 1559]}

Voor de schoorsteen, een oud stuck, gedaen, als onder op de lijst. 1531. Sijn[de] 2 hoogh, en[de] in [de] bovenste rij een met een musijckboeck.

De 2 deuren, op dit stuck gehoorende sijn, besijde de voors[eide] schoorsteen, doch gedaen 28 jaren later, namentl[ijk] Ao 1559 als op ijder deur, aen [de] helft van dit cijffer getal te sien is: aen [de] sijde na de straet staet aldus op de boven en[de] onder lijst: "Het lustige rot van de Letter L. Cap[itei]ns gebod voldoen sij snell. 15="

Aen [de] andere sijde ter sijden aen [de] schoorsteen, op de ander deure, staat aldus gerijmt: "Tweedrachtige spot en Toornicheyt fell. Keer van haer, God v[an] Israhel =59".

\section{[in kantlijn $\gamma$ Ao 1529]}

Noch op de selve ghroote kamer. Een stuck tegen over 't inkomen van [de] deur. Hangen[de] om laegh. Alwaer ter sijden op de lijst staet “Trijn is hier komen wonen 1529". En[de] staett dese woorden omtrend daar een Oude-Vrou in t' selve bort geschildert is, hebben[de] een schotel met 
appelen.

\section{[in kantlijn $\delta$ Ao 1558]}

Aen [de] andere sijde van [de] schoorsteen oock so laegh, is noch een oud stuck van 't jaer 1558. H. waer in een met een blad musijck, daer in dese woorden. "Een man Een Wijf", op musijcnoten.

\section{[in kantlijn $\varepsilon$ Ao 1623]}

Boven deze twee laetste stucken, sijn noch aen elcke sijde van de schoorsteen een helft van 't stuck, daer in cap[itei]n in is Jacob Gerritsz Hoinck naer de straetsijde en[de] tot lut[enant] Pieter Hasselaer. naer de doelens sij. van Ao 1623.

\section{[in kantlijn $\xi$ Ao 1604]}

Op de selve kamer tegen het middelschot, boven de deur, waer in Cap[itei]n is ...... en[de] lutenant ...... staen[de] op de lijst. 1604.

\section{[in kantlijn $\eta$ Ao 1604]}

Ibid. daer raex aen, na de straets-sijde, Het tafereel daer cap[itei]n is ...... en[de] lut[ena]n[t] ...... staen[de] op de lijst. 1604.

Op de grootte sael

Voor de schoorsteen, ledich, sijn[de] t' stuck, twelck daer tot noch toe gehangen hadde, gebracht op de kleine camer boven de poort. de qua postea. Sullen[de] de 4 overluijden, burgem[eester] Frans Benning Cock, en[de] de 3 schepens, Poll, Pater, en[de] Blaeu, haer doen schilderen, en[de] aldaer opgehangen worden.

[in kantlijn $\boldsymbol{\theta}$ Ao ....]

Ter sijden die schoorsteen, na de doelen toe, is het stuck daer ... Poppen cap[itei]n is en[de] ...... lut[enant]. Sitten aen een ongedeckte tafel.

[in kantlijn ı Ao ....]

Ter sijden de andere sij van [de] schoorsteen, is Geurt Dircksz. v[an] Beuningen cap[itei]n en[de] lut[enan]t ..... dit stuck is geschildert bij ... Tengnagel, naemaels onderschout.

[in kantlijn $\kappa$ Ao 1585]

Tegen het middelschot, na de straetsijde, is het stuck v[an] Ao 1585 sijn[de] 2 hoogh, geschildert, door ... Barentsz.

[in kantlijn $\lambda$ Ao 1595]

Ibid. tegen het selve middelschot, na de doelens sijde, t' stuck van Ao 1595. Als in de bovenlijst, in [de] onderlijst staet, Christianus de Conflans F.

[in kantlijn $\boldsymbol{\mu}$ Ao 1535]

Ibid. boven de deur, een oud stuck met tabbaerden v[an] root en[de] groen. Staen[de] onder op de lijst. Ao. DNI. 1535. 
[in kantlijn $v$ Ao ....]

Op de grootte Camer over de gang, is een stuck daer in[ne] als 8 of 10 jongeluijden geschildert sijn, met musquetten, onder de welcke is ... Oetges, scheel van gesight wesen[de], geschildert door ... Tengnagel, [daar]na onderschout.

\section{[in kantlijn $\rho$ Ao 1533]}

Op de kleine kamer boven de poort, tusschen de schoorsteen en [de] straet hanght het stuck, gekomen van voor de schoorsteen wt de grootte sael. sijn[de] van [de] jaere 1533. en[de] alle mael een pijll hebben[de] in [de] hand, in t' midden de coninck van 't papegaeij schieten met de scepter in sijn hand:

\section{[in kantlijn o Ao 1650]}

Op de grootte kamer boven de poort, het nieuwe stuck daer scepen Jan van der Poll, cap[itei]n ende sijn broeder Gijsbert van der Poll lut[enant] sijn. gescildeert van Jan Spilbergh. Ao 1650.

\section{[in kantlijn $\tau$ Ao 1566]}

In't voorhuijs.

Inkomen[de] aen [de] rechter hand, 2 stucken, doch aen, of bij een, gehooren[de], van de Jare 1566 , als boven, en[de] op de lening van een stoel, te sien is.

\section{[in kantlijn v Ao 1586]}

Daer tegen over, een stuck gedaen bij Dirck Barentsz, daer cap[itei]n is Egbert Vinck, lut[ena]n[t] ...... Ao 1586 staen[de] na de straetssijde.

[in kantlijn $\varphi$ Ao 1603]

Item daer raex aen, na de doelens toe, het stuck daer cap[itei]n is Pieter Adriaensz Raep, lut[ena] $\mathrm{n}[\mathrm{t}]$... van der Hem, gedaen 1603.

NB.

Dese overluijden hebben van ijder stuck een schets op papier laten maken, door ...... schilder, om alle de namen [daar]bij te teijckenen, ad perpetuam memoriam quo ad in posterum reperiri poterit.

\section{Memorie en[de] lijst van [de] publ[ieke] schilderien op de Voetbooghs-Doelen. Soo als die waren in febr[uarij] Ao 1653.}

[in kantlijn a Ao 1648]

Op d' oude sael voor de schoorsteen, schepen Corn[e]l[i]s Witsen cap[itei]n. Jan Oetges v[an] Waveren lut[enant] geschildert Ao 1648 van Bartelmeeus vand[er] Helst.

[in kantlijn $\beta$ Ao 1645]

Ibid. tersijden na de plaets van [de] Doelen, het stuck v[an] cap[itei]n Jacob Rogh, en[de] Anto[nie] de Lange lut[enant], geschildert p[er] Claes Elias Ao 1645. 
[in kantlijn $\gamma$ Ao 1579]

Ibid. boven de deur, Jan Huijdekoop[er] d'oude, cap[itei]n, en[de] ..... geschildert Ao 1579.

[in kantlijn $\delta$ (Latere hand:) Ao 1650]

Ibid. tegen t' middelschot, cap[itei]n Jan Huijdekooper de jonge, en[de] Frans v[an] Waveren lut[enan]t, geschildert Ao 1650 bij Govert Flinck.

[in kantlijn $\varepsilon$ Ao 1553]

Ibid. achter t' stuc voor de schoorsteen hanght het oude stuck A. van Ao 1552. daer de schutters het teijcken op de mou v[an] haer tabbaerden dragen.

[in kantlijn $\zeta$ Ao 1625]

Op de andere bovenkamer, S[in]t Joris gen[aem]pt, voor de schoorsteen, daer schepen Albertus Coenradi cap[itei]n is en Pieter Evertsz Hulft sijn lut[enant]. 1625. geschildert bij ... Vlack:

\section{[in kantlijn $\eta$ Ao 1618]}

Ibid. boven t' middelschot, cap[itei]n Arent ten Grootenhuijs. lut[enant] Nanning Florisz. Cloeck. Geschildert bij Frans Barentsz. Ao 1618.

\section{[in kantlijn $\theta$ Ao 1623]}

Ibid. aen [de] doelens sijde, 9 of 10 personen van t' hooft tot te voeten sijn[de] cap[itei]n Abraham Boom, lut[enant] Anto[nie] Oetges. Welck stuck begonnen is bij ... Lastman, doch vermits sijn dood voorts affgeschildert bij ... Nuland.

Dese comp[a]g[ni]e had buitten de stad tot Swoll in garnisoen geweest.

[in kantlijn I Ao 1555]

Ibid. ter sijden de schoorsteen, is een oud stuck getekend C. 1555.

[in kantlijn $\kappa$ Ao 1564]

Ibid. en[de] onder t' voorgaen[de], het stuck get[ekend] G. Ao 1564. geschildert bij Dirck Barentsz.

[in kantlijn $\lambda$ Ao 1628]

Op de kamer t' Stick gen[aem]pt. Inkomen[de] aen[de] rechter hand cap[itei]n Jacob Pietersz Hooghkamer, lut[enant] Pieter Jacobsz v[an] Rijn geschildert Ao 1628 bij ... Lijon.

[in kantlijn $\mu$ Ao 16..]

Ibid. voor de schoorsteen, cap[itei]n Mathijs Willemsz. Raephorst en[de] lut[ena]n[t] Hendric Lourisz Boeckverkoop[er] op t'water, geschildert bij Claes Elias Ao ....

[in kantlijn v Ao 16..]

Ibid. naest de schoorsteen. Cap[itei]n Jacob Backer, en[de] Jacob Rogh lut[enant]. geschildert bij Claes Elias, Ao 16. 
[in kantlijn $\rho$ Ao 1554]

Op de kamer No 4 gen[aem]pt: een oud stuck van Ao 1554 E.

[in kantlijn o 1559]

Ibid. een oud stuck van Ao 1559, getekend B.

[in kantlijn $\tau$ 1564]

in [de] gang [daar]tegen over. een stuck get[ekend] K boven op de lijst Ao 1564.

[in kantlijn v 1533]

Op de kamer No 5./ Een oud stuck sitten[de] aen [de] tafel daer een gebraden reijger in [de] schotel leijd. get[ekent] (:alij D dicunt:) 1533.

ubi S.B. in flore aetatis, vide in senectute alibi supra

[in kantlijn $\varphi$ 1588]

Op de kamer No 6. Een stuck van 15A88. Hier in staet schout Verdoel.

[in kantlijn $\chi$ 1553]

Ibid. Noch een oud stuck get[ekent] A.D. 1553.

[in kantlijn $\psi$ 1555]

Ibid. noch een get[eekent] (:G credo:) Ao 1555. [daar] onder een is die op een brief heeft pro sijmbolo ex a $[\mathrm{n}] \mathrm{i}[\mathrm{m}] \mathrm{o}$ o[mn]ia.

[in kantlijn $\omega$ 1551]

In t'portael bij de trap na beneden gaen[de], staet op de lijst van een stuck Anno D[omi]ni 1551.

[in kantlijn aa 1633]

Beneden de nieuwe sael, tegen over de glaesen, cap[itei]n Jacob Sijmonsz de Vries, lut[enant]

Dirck Graef. Ao 1633 geschildert v[an] Tho[mas] Keijser.

[in kantlijn $\beta \beta$ 1637]

Ibid. tegen over de schoorsteen, cap[itei]n Reijnier Reael, lut[ena]nt Cornelis Michielsz Blau, Ao 1637 bij Francois Hals begonnen, en[de] bij Codde voorts opgemaeckt.

[in kantlijn $\gamma \gamma$ 1588]

In t' voorhuis tegen de binnenheert aen, ... Rosencrants cap[itei]n en[de] lut[enant] ... Pau. Ao 1588 bij Ketel geschildert.

[in kantlijn $\delta \delta$ 1599]

Ibid. daer tegen over, Jillis Jansz Valckenier cap[itei]n Pieter Bas lut[ena]n[t]. Ao 1599 gedaen bij Pieter IJsaxsz: die [daar]na resid[en]t wierde in [de] Sond.

Memorie en[de] lijst van [de] schilderijen op de Cloveniers doelen. [in kantlijn: 7 op de grootte kamer boven] 
Voor de schoorsteen op de grootte sael, de 4 overluijden, burgem[eester] Albertus Conradi, Pieter Reael, ontfanger van [de] gemeene middelen v[an] Holl[an]t, Jan Claessen Vlooswijck, en[de] Jacob Willkes. Geschildert bij Govert Flinck.

Ibid. aen [de] rechter sijde van [de] schoorsteen, na den Aemstel toe, cap[itei]n Cornelis Bicker, heer v[an] Swieten, lut[enant] Fred[erick] v[an] Banchem de notaris. geschildert van ... Sandraert. Ao 1640.

Ibid. aen [de] slijncke-sijde, Albert Bas cap[itei]n, Lucas Conijn lut[enant] gedaen bij Govert Flinck. 1645.

Ibid. daer naest aen volgen[de] Frans Benning Cock cap[itei]n en[de] Will[em] van Ruijtenburg lut[enant] geschildert van Rembrand Ao 1642.

Ibid. volgende als voren Jan Claesz Vlooswijck cap[itein], Gerrit Hudde lut[enant] gedaen Ao .... bij ......

Ibid. Cornelis Graef. cap[itei]n. Hendric Lourisz Boeckverkooper, geschildert bij JABacker [JAB in ligatuur] Ao 1642.

Ibid. voor de schoorsteen aen t'inkomen. Roelof Bicker. cap[itei]n. Jan Michielsz Blau. Lut[enant]. Ao 1643. Gedaen bij Bartel[o]m[eus] van der Helst.

\section{[in kantlijn: 5 in t' voorhuijs]}

Voor in t' voorhuijs, boven de trap gaen[de] na de grootte sael Allaert Cloeck schepen cap[itei]n. Lucas Jacobsz Rotgans lut[ena]nt. Ao gedaen bij ... Keijser.

Ibid. in t' voorhuijs, [daer]naest aen volgen[de]. Dirck Theuling cap[itei]n en[de] Adriaan Pietersz Raep. lut[enant] gedaen Ao 1639 bij Claes Elias.

Ibid. in t' voorhuijs tegen over t' inkomen van [de] straet. Den ouden Pieter Dirxsz Hasselaer. cap[itei]n. Jan Gerritsz Hooft. lut[enant].

Ibid. tegen de muer van [de] Conings-kamer, den ouden Jacob Cappit. Cap[itei]n ...... lut[enan] t geschildert bij Dirck Barentsz.

Ibid. tegen de muer van [de] Prince Camer Dirck Jacobsz Rosecrans. cap[itei]n ... Ruysch. Lut[enant]. gedaen bij Ketel.

\section{[in kantlijn: in alles 12 stucken]}

\section{[in kantlijn: 6 stucken op de 2 kamers in t'voorhuijs wtgaende]}

Naest het voorhuijs op de Conings-kamer, staen[de] aen [de] Water-sijde.

Voor de schoorsteen, een oud-stuck met 2 deuren, get[ekend] M Ao 1559.

Aen [de] muer tegen over de glasen. Schepen Spiegel. cap[itei]n. Jacob Servaes lut[ena]n[t]. Ao 1638 geschildert bij JABacker [JAB in ligatuur]. 
In [de] selve Camer over de schoorsteen. Een oud stuck, bij Dirck Barentsz geschildert. Ao .... Op de Prince-kamer, aen t' voorhuijs na de straet-sijde Voor de Schoorsteen een oud stuck get[ekend] F Ao ....

Ibid. een stuck daer Jan de Bisschop cap[itei]n is en Pieter Egbertsz Vinck vaendrigh.

Ibid. noch een oud-stuck.

\section{[in kantlijn: Op t' haertgen: 7]}

Op de camer gen [aem]pt het Haertgen

een stuck daer maer 3 personagien in sijn, waeronder die met een gesneden wambuis en[de] mouwen geseid word den col[onel] Ruijghaver te sijn.

Ibid. boven de deur, komen[de] van beneden, een oud stuck met gele en[de] groene rocken. van Ao ....

Ibid. Jacob Gerritsz Hoing cap[itei]n, .... Appelman lut[enant], Ao ....

Ibid. over t' Lict-du-camp. een oud stuck, get[ekend] K.

Ibid. noch een oud stuck, get[ekend] B Ao 1556.

Ibid. het stuck met de XVII personagien in t' blancke harnasch Ao 1531.

Ibid. noch een lang smal stuck van weynich $\mathrm{p}[\mathrm{er}]$ sonagien.

[in kantlijn: 4]

Op de grootte Heere-kamer. sijnde raex aen [de] Brugh

boven de deur, Jonas Witsen cap[itei]n. Volckert Overlander lut[enant] geschildert bij Cornelis vand[er] Hoogh.

Ibid. Jacob Gerritsz Hoing cap[itei]n. Nanning Florisz Cloeck lut[enant]. Ao 1616 geschildert.

Ibid. Albert Jonckein. capitein. ...... lutenant. Geschild[ert] Ao 1606.

Ibid. voor de schoorsteen, eenige schutters met haer doelroers.

[in kantlijn: 17 stucken soo groot als klein oud en moderne]

Op het portael, of den deurgang nae de voorgem[elde] Heere Camer.

\section{[in kantlijn: 1]}

Een oud stuck. daer mijn overgroote vader Jacob Schaep Pietersz voor aen staet. doch word meest onkendbaer door het afschilferen.

Op het rond

\section{[in kantlijn: 5]}

Een stuck boven de deur.

Item voor de schoorsteen.

Ibid. in de hoeck. 2 stucken bij een gevoeght. Get[ekend] E. 1561.

Ibid. een stuck geschildert bij Dirck Barentsz. Gen[aem]pt de Pos-eters.

Ibid. noch een stuck van 8 p [er] sonen.

Op schutterskamer

\section{[in kantlijn: 2]}

2 stucken ijder van .. schutters met haer doelroers, modern.

Op de kleine Heerekamer 
[in kantlijn: 2]

Een oud stuck, met gele rocken. Van Ao 1534.

Ibid. noch een oud stuck met 2 deuren. van Ao 1529.

[in kantlijn: 10 stucken $+17+12=39$ ]

${ }^{1}$ Tom van der Molen made the new transcription.

${ }^{2}$ SAA 5059: Collectie Stadsarchief Amsterdam: Handschriften, nos. 41-44; "Handschriften van

Gerrit Pietersz. Schaep betreffende de geschiedenis van Amsterdam, ongedateerd" (Manuscripts by Gerrit Pietersz Schaep, regarding the history of Amsterdam, undated). The document "Record and list of the public paintings kept at the three civic guard halls: as I have found them, after my return to Amsterdam in February 1653" can be found in no. 43: no. 3: Schutterijen, ambten, colleges, onderwijs, godshuizen" [civic guards, professions, governing bodies, education, churches]. This document was originally published in Dutch by Pieter Scheltema, "De schilderijen in de drie doelens te Amsterdam, beschreven door G. Schaep, 1653," in Aemstel's oudheid of gedenkwaardigheden van Amsterdam, vol. 7 (1885), 121-41 (available online: http://dbnl.org/arch/sche078aems07_01/pag/sche078aems07_01.pdf). But several small errors in Scheltema's transcription have prompted me to make a new transcription as a basis for the translation.

${ }^{3}$ Schaep returned from England to Amsterdam earlier that year.

${ }^{4}$ In 1897, Six made a first attempt at matching paintings that survived in the collection of the city of Amsterdam with those that Schaep's manuscript mentioned as being in the Handboogsdoelen (Longbow Archers Civic Guard Hall). See Jan Six, "De schilderijen in den Handboogsdoelen," Oud Holland 15 (1897): 129-38. For the Handboogsdoelen, several other documents have also proved useful: Christoffel Beudeker, Oudheden van Amstelredamme, met aanteekeningen opgehelderd, meerendeels door Abraham Rademaker getekent, benevens een korte beschrijvinge van de oude Schutters Doelen derzelver stad / uit liefhebberij vergaderd en beschreven door Christoffel Beudeker (with sketches after the civic guard portraits in the Longbow Archers Civic Guard Hall and notes of names and heraldic weapons of depicted militia companies) [Manuscript in the library of the Amsterdam City Archives]. Also the notes by Hans Bontemantel in De regeeringe van Amsterdam, soo in 't civiel als crimineel en militaire (1653-1672), ed. G. W. Kernkamp (The Hague: Nijhof, 1897), 1:186 n 1.

(available online: http://www.dbnl.org/titels/titel.php?id=bont014rege01) The discovery of MS Egerton 983 in 1903 in the British Library, with watercolor copies after the paintings by Colijns, and lists of the names of the sitters included (see note 24 below), allowed Six to further refine his reconstruction of the paintings in this Civic Guard Hall (MS Egerton, Arms, in colors, of the Masters of the Hand-bow Company of Amsterdam, 1477-1659: Portraits and arms of members of the same Company, for the same period;Large oblong Quarto (Manuscript in the British Library, Bibl. Eg. 983). See Jan Six and W. Del Court, "De Amsterdamsche Schutterstukken," Oud Holland 21 (1903): 65-80.

${ }^{5}$ MS Egerton 983, fol. 21; Bontemantel,Regeeringe, 10; Six and Del Court, "Schutterstukken," 68, 74 , pl. I. 
${ }^{6}$ MS Egerton 983, fol. 27; Beudeker, Oudheden, G; Bontemantel,Regeeringe, 9; Six and Del Court, "Schutterstukken," 69, 74-75, pl. VII (Dirck Barendsz.?).

MS Egerton 983, fol. 23; Six and Del Court, "Schutterstukken,” 68, 74, pl. IV (Dirck Jacobsz.?). ${ }^{8}$ Cornelis van der Voort, Company of Adriaen Pietersz Raep and Dirck Hasselaer, 1623, Amsterdam Museum, inv. no. SA 3020; and Cornelis van der Voort, Company of Pieter Dirksz Hasselaer, 1623, Amsterdam Museum, inv. no. SA 9909; MS Egerton 983, fols. 17 and 19; Beudeker, Oudheden, F, 7; Pieter Scheltema, Historische beschrijving der schilderijen van het stadhuis te Amsterdam (Amsterdam: Stadsdrukkerij, 1879), nos. 127 and 128; Six and Del Court, "Schutterstukken," $68,76$.

${ }^{9}$ Gerrit Pietersz, Company of Captain Jan Jansz Carel and Lieutenant Thijs Pietersz Schrijver, 1604, Amsterdam Museum, inv. no. 7389; MS Egerton 983, fol. 31; Beudeker, Oudheden, I, 5; Bontemantel, Regeeringe,7; Scheltema,Historische beschrijving, no. 132; Six and Del Court, "Schutterstukken," 69, 75

${ }^{10}$ Aert Pietersz, Company of Pieter van Neck [fragment], Amsterdam Museum, inv. no. SA 3018. Additional fragments in the Amsterdam Museum, inv. nos. SA 3037 and SA 3038; MS Egerton 983, fol. 29; Beudeker, Oudheden,H, 2; Bontemantel,Regeeringe,8; Jan Van Dyk, Kunst en Historiekundige beschryving en aanmerkingen over alle de schilderyen op het Stadhuis te Amsterdam (Amsterdam: Yver, 1758), no. 116 (Moreels) (Available online: http://books.google.nl/ books?id=UMA9AAAAcAAJ\&hl=nl\&pg=PP11\#v=onepage\&q\&f=false); Scheltema, Historische beschrijving, nos. 121, 167, and 168; Six and Del Court,"Schutterstukken," 69, 73, 75, 78.

${ }^{11}$ Bartholomeus van der Helst, The Governors of the Crossbow Archers Civic Guard, 1653, Amsterdam Museum, inv. no. SA 7329; MS Egerton 983, fol. 3; Scheltema, Historische beschrijving, no. 41; Six and Del Court, "Schutterstukken," 66, 76.

${ }^{12}$ MS Egerton 983, fol. 7; Beudeker,Oudheden, A, 4; Six, "Schilderijen in den Handboogsdoelen," pl. III; Six and Del Court, "Schutterstukken," 67, 75 (Pieter Isaacsz, ca. 1596-99).

${ }^{13}$ Jan Tengnagel, Company of Captain Geurt van Beuningen and Lieutenant Pieter Hoefijzer, 1613, Amsterdam Museum, inv. no. SA 7408; MS Egerton 983, fol. 9; Beudeker, Oudheden, B; Scheltema Historische beschrijving, no. 126; Six and Del Court, "Schutterstukken," 67, 75 ${ }^{14}$ Anonymous, Company of Captain Reynst Pietersz and Ensign Claes Claesz Kruys, 1585, Amsterdam Museum, inv. no. SA 7289; MS Egerton 983, fol. 11; Beudeker, Oudheden, C; Bontemantel, Regeeringe, 13; Van Dyk,Kunst, no. 117 (Ketel); Scheltema, Historische beschrijving, no. 76 (P. Moreelse); Six and Del Court, "Schutterstukken," 67, 73, 75, 78.

${ }^{15}$ Adriaen van Conflans, Company of Captain Dirk Thymansz. Brouwer and Lieutenant Ryckert Ouwerol, 1595, Amsterdam Museum, inv. no. SA 7303; MS Egerton 983, fol. 13; Beudeker, Oudheden, D; Bontemantel, Regeeringe, 12; Van Dyk, Kunst, no. 114 (Alion); Scheltema, Historische beschrijving, nos. 118, 131, 135; Six and Del Court, "Schutterstukken," 68, 73, 78, pl. IX. ${ }^{16}$ MS Egerton 983, fol. 15 (Captain Braseman and Lieutenant Bikker); Beudeker,Oudheden, E; Bontemantel, Regeeringe,11; Six and Del Court, "Schutterstukken," 68, 74, pl. III.

${ }^{17}$ MS Egerton 983, fol. 33; Beudeker, Oudheden, K; Bontemantel, Regeeringe, 6; Six and Del Court, "Schutterstukken," 69, 76, pl. X (Tengnagel, 1619-26).

${ }^{18}$ Parrot shooting was a yearly contest in which a wooden bird was shot off a high pole. The winner was crowned king.

${ }^{19}$ MS Egerton 983, fol.44; Six and Del Court, “Schutterstukken,”70, 74, pl. II.

${ }^{20}$ Johannes Spilberg, Company of Captain Jan van de Poll en Lieutenant Gijsbert van de Poll, 1650, Amsterdam Museum, inv. no. SA 7406; MS Egerton 983, fol. 46; Scheltema, Historische 
beschrijving, no. 104; Six and Del Court," "Schutterstukken," 71, 76.

${ }^{21}$ MS Egerton 983, fol. 39; Beudeker,Oudheden, M, 1; Bontemantel, Regeeringe, 2; Jan Six, "De schilderijen in den Handboogsdoelen," 129-38, pl. I, Six and Del Court, "Schutterstukken," 70, 75 (Pieter Isaacsz?, 1596?).

${ }^{22}$ Karel van Mander, Het Schilderboeck (Haarlem, 1604)(available online: http://dbnl.org/tekst/ mand001schi01_01/), f. 259v: "Noch isser op S. Sebastiaens Doelen een schoon heerlijck Rot, waer in comen eenige bruyn oude Schippers tronien, en boven op een galerije zijnder, die eenen grooten silveren drinck-hoorn hebben, en is heerlijck en wel ghedaen: Soo datmen in dit en ander zijn wercken siet een treflijcke Titiaensche en Italiaensche handelinghe." ) (Translation from Karel van Mander, The Lives of the Illustrious Netherlandish and German Painters from the first edition of the Schilder-boeck (1603-1604), ed. Hesssel Miedema [Doornspijk, 1994], 1:297): Then, in the St. Sebastian's Doelen, there is a beautiful, dignified company in which there are some tanned old sailors' faces and in a gallery above there are some holding a large silver drinking-horn, it is well and splendidly executed. Thus, in this and in other works of his one sees a striking Titianesque and Italian manner of working.); MS Egerton 983, fol. 35; Beudeker, Oudheden, L, 4; Bontemantel, Regeeringe,4; Six and Del Court, "Schutterstukken,"70, 75, pl. VIII.

${ }^{23}$ MS Egerton 983, fol. 37; Beudeker,Oudheden, (N) 3; Bontemantel, Regeeringe, 3; Van Dyk, Kunst, no. 115 (Moreels); Six, "Schilderijen in den Handboogsdoelen," pl. II, Six and Del Court, "Schutterstukken,"70, 74, 75 (Aert Pietersz?).

${ }^{24}$ The sketches were made by David Colijns (1582-1664/66) and are currently kept in the British Library in London (Arms, in colors, of the Masters of the Hand-bow Company of Amsterdam, 1477-1659: -Portraits and arms of members of the same Company, for the same period; Large oblong Quarto, Bibl. Eg. 983) The manuscript contains two portraits not mentioned by Schaep: MS Egerton 983, fol. 25 (Beudeker, Oudheden G; Six and Del Court, "Schutterstukken,"68, 74, pl. VI) and MS Egerton 983, fol. 42 (Bontemantel,Regeeringe, 1; Six and Del Court, "Schutterstukken," 70, 74, pl. V [1562]).

${ }^{25}$ Bartholomeus van der Helst, The Four Governors of the Crossbow Archers Company (Voetboog?), 1656, Amsterdam Museum, inv. no. SA 7330, had not yet been painted when Schaep made his list. See Van Dyk,Kunst, no. 43; Scheltema, Historische beschrijving, no. 38.

${ }^{26}$ Bartholomeus van der Helst, Company of Captain Cornelis Witsen and Lieutenant Johan Oetgens van Waveren Celebrating the Treaty of Münster, 1648, Rijksmuseum Amsterdam, inv.no. SK-C-2, on loan from the city of Amsterdam, inv. no. SA 7328; Van Dyk, Kunst, no. 24; Scheltema, Historische beschrijving, no. 40.

${ }^{27}$ Nicolaes Eliasz Pickenoy, Company of Captain Jacob Rogh en Lieutenant Anthonie de Lange, 1645, Amsterdam Museum, inv.no. SA 7315; Van Dyk, Kunst, 1758, no. 21 (as J. Backer); Scheltema, Historische beschrijving, no. 7 (as Backer).

${ }^{28}$ Six and Del Court, "Schutterstukken," 76.

${ }^{29}$ Govert Flinck, Company of Captain Joan Huydecoper and Lieutenant Frans van Waveren celebrating the treaty of Münster, 1650, Amsterdam Museum, inv. no. SA 7318; Van Dyk, Kunst, no. 25 (as G. Flinck); Scheltema, Historische beschrijving, no. 33 (as G. Flinck). (The painting is signed and dated 1648. There are good reasons to believe that Flinck actually finished the painting in 1650 , but signed it 1648 as a memento of the peace celebrations in that year.)

${ }^{30}$ Van Dyk, Kunst, no. 13 (as Dirk Cornelissen).

${ }^{31}$ Werner van den Valckert, Company of Captain Albert Coenraetsz Burgh and Lieutenant Pieter Evertsz Hulft, 1625, Amsterdam Museum, inv. no. SA 7420; Van Dyk, Kunst, no. 19 (as P. 
Moreelse); Scheltema, Historische beschrijving, no. 108 (as W. v.d. Valckert).

${ }^{32}$ Frans Badens, Company of Captain Arent ten Grootenhuys and Lieutenant Jacob Florisz Cloeck, ca. 1613, Amsterdam Museum, inv. no. SA 7258; Scheltema, Historische beschrijving, no. 77.

${ }^{33}$ Nicolaes Lastman en Adriaen van Nieulandt, Company of Captain Abraham Boom and Lieutenant Oetgens van Waveren, 1623, Amsterdam Museum, inv. no. SA 7361; Van Dyk, Kunst, no. 18; Scheltema, Historische beschrijving, no. 125.

${ }^{34}$ Van Dyk, Kunst, no. 12 (as Jacob Cornelisz).

${ }^{35}$ Dirck Barendsz, Civic Guardsmen of Squad G, 1562, Amsterdam Museum, inv. no. SA 7287; (possibly) Van Mander, Schilderboeck, f. 259v: "op de Voetbooghs Doelen een Rot, waer in een Ketelaer comt, en is wonder wel gehandelt" (Firstly at the Crossbow Doelen a company in which there is a drummer, and that is astonishlingly well executed). Translation from The Lives of the Illustrious Netherlandish and German Painters (see note 22 above), vol. 1, p. 297. See also Van Dyk, Kunst, no. 3 (as Dirk Barentsz); Scheltema, Historische beschrijving, no. 11 (as Dirk Barentsz).

${ }^{36}$ Jacob Lyon, Company of Captain Jacob Pietersz Hooghkamer and Lieutenant Pieter Jacobsz van Rijn, 1628, Amsterdam Museum. inv. no. SA 998; Van Dyk Kunst, no. 16 (as A. Lion); Scheltema, Historische beschrijving, no. 71 (as A. Lion).

${ }^{37}$ Nicolaes Eliasz Pickenoy, Company of Captain Matthijs Willemsz Raephorst and Lieutenant Hendrick Lauwrensz, 1630, Amsterdam Museum, inv. no. SA 7312; Van Dyk,Kunst, no. 17 (as A. Lion); Scheltema, Historische beschrijving, no. 70 (as A. Lion).

${ }^{38}$ Nicolaes Eliasz Pickenoy, Company of Captain Jacob BackerandLieutenant Jacob Rogh, 1632, Amsterdam Museum, inv. no. SA 7313; Van Dyk, Kunst, no. 104 (as P. Moreelse); Scheltema, Historische beschrijving, no. 75 (as P. Moreelse).

${ }^{39}$ Master of the Antwerp Family Portrait, Civic Guardsmen of Squad E, 1554, Amsterdam Museum, inv. no. SA 7345; Van Dyk, Kunst, no. 14. (as Dirk Cornelisz); Scheltema, Historische beschrijving, no. 47 (as Dirck Jacobsz).

${ }^{40}$ Master of the Antwerp Family Portrait, Twenty-one Civic Guardsmen of Squad B, 1559, Amsterdam Museum, inv. no. SA7346; Van Dyk,Kunst, no. 8; Scheltema, Historische beschrijving, no. 48. ${ }^{41}$ Van Dyk, Kunst, no. 7 (as Dirk Jacobsz).

${ }^{42}$ Cornelis Anthonisz, Meal of a Squad of Civic Guardsmen of the St. George Militia Guild, 1533, Amsterdam Museum, inv. no. SA 7279; Van Dyk, Kunst, no. 1 (as Cornelis Anthonisz); Scheltema, Historische beschrijving, no. 1 (as Cornelis Anthonisz).

${ }^{43}$ Anonymous, Civic Guardsmen of Squad A, 1588, Amsterdam Museum, inv. no. SA 7290; Van Dyk, Kunst, no. 4 (C. Ketel); Scheltema,Historische beschrijving, no. 54 (as C. Ketel); Six and Del Court, "Schutterstukken," 77 (as Dirck Barendsz).

${ }^{44}$ Van Dyk, Kunst, no. 5 (as Dirk Jacobsz).

${ }^{45}$ Possibly: Anonymous, Squad of Civic Guardsmen, ca. 1555, Amsterdam Museum, inv. no. SA 2128; Van Dyk, Kunst, no. 6 (as Cornelis Anthonisz); Scheltema, Historische beschrijving, no. 2 (as Cornelis Anthonisz). "Ex animo omnia" is taken from Terence's Andria, act 4, lines 794-95: "paullum interesse censes ex animo omnia, ut fert natura, facias an de industria?" See also Judith van Gent, "Dit in mijn stamboek te leggen': het dossier van Nicolaes Witsen in Brielle," Face Book: studies on Dutch and Flemish Portraiture of the 16th-18th Centuries, p. 456-457.

${ }^{46}$ Van Dyk, Kunst, no. 11 (as Cornelis Anthonisz).

${ }^{47}$ Thomas de Keyser, Company of Captain Jacob Symonsz de Vries and Lieutenant Dirck de Graeff, 1633, Amsterdam Museum, inv. no. SA 7354; Scheltema, Historische beschrijving, no.55 (as Thom- 
asde Keyser).

${ }^{48}$ Frans Hals and Pieter Codde, Company of Captain Reinier Reael and Lieutenant Cornelis Michielsz Blaeuw(known as the Meagre Company), 1639, Rijksmuseum Amsterdam, inv. no. SKC-374, on loan from the city of Amsterdam (SA 7321); Van Dyk, Kunst, no. 20 (as Hals); Scheltema, Historische beschrijving, no. 36 (as Hals).

${ }^{49}$ Cornelis Ketel, Company of Dirck Jacobsz Rosecrans and Lieutenant Pauw, 1588, Rijksmuseum, Amsterdam, inv. no. SK-C-378, on loan from the city of Amsterdam (SA 7350); (possibly) Van Mander, Schilderboek, f. 275v: "In 't jaer 1589 leverde hy noch een corporaelschap op de Handtboogh-doelen, daer capiteyn af was Dirck Roosecrans, also groot als t' leven al over eynde staende, seer heerlijck gheschildert, en cierlijk om aensien, met oock een nieuw inventie van een lijst" (In the year 1589 he produced yet another corporalship for the Archers' doelen, of which Dirck Roosecrans was the captain, as large as life, everyone standing up, very grandly painted and richt o look upon, with also a new invention as regards the framing). Translation from The Lives of the Illustrious Netherlandish and German Painters (see note 22 above), 1:361. See also Van Dyk, Kunst, no.15; Scheltema, Historische beschrijving, no. 53.

${ }^{50}$ Pieter Isaacsz, Company of Captain Gillis Jansz Valckenier and Lieutenant Pieter Jacobsz Bas, 1599, Rijksmuseum, Amsterdam, inv.no. SK-C-455, on loan from the city of Amsterdam (SA 7339); Scheltema, Historische beschrijving, no. 129; Six and Del Court, "Schutterstukken," 77. ${ }^{51}$ This room in the Arquebusiers Civic Guard Hall (Kloveniersdoelen) has been extensively studied, for the obvious reason of the presence of Rembrandt's Nightwatch there. Most recently Dudok van Heel has made an elaborate reconstruction of the room and its ensemble of civic guard portraits: S.A.C. Dudok van Heel, “'The Night Watch' and the Entry of Marie de'Medici: A New Interpretation of the Original Place and Significance of the Painting," Rijksmuseum Bulletin 57, no. 1 (2009): 4-41. See also Gary Schwartz, The Night Watch(Amsterdam/Zwolle: Rijksmuseum/ Waanders, 2002).

${ }^{52}$ Govert Flinck, Governors of the Kloveniersdoelen, 1642, Rijksmuseum, Amsterdam, inv. no. SK-C-370, on loan from the city of Amsterdam (SA 7316), currently on loan to the National Gallery of Art, Washington, D.C., until March 2017; Scheltema, Historische beschrijving, no. 31. Since the painting is not mentioned by Van Dyk, it was probably still in the Kloveniersdoelen at that time; a print from 1748 in the Amsterdam City Archives showing the room seems to support this supposition. The places where the two paintings next to the governors' portrait used to hang (the Company of Cornelis Bicker and the Company of Albert Bas) are empty (they had already been brought to the City Hall), but the chimney piece contains a portrait of four men around a table. Although the scene depicted in the print differs completely from what is visible in Flinck's portrait, it can be safely assumed that the printmaker does refer to the portrait by Flinck hanging above the chimney.

${ }^{53}$ Joachim von Sandrart, Company of Cornelis Bicker and Lieutenant Frederick van Banchem, 1638-40, Rijksmuseum, Amsterdam, inv. no. SK-C-393, on loan from the city of Amsterdam (SA 7399); Van Dyk, Kunst, no. 54; Scheltema, Historische beschrijving, no. 101.

${ }^{54}$ Govert Flinck, Company of Albert Bas and Lieutenant Lucas Conijn, 1645, Rijksmuseum, Amsterdam, inv. no. SK-C-371, on loan from the city of Amsterdam (SA 7317); Van Dyk, Kunst, no. 52; Scheltema, Historische beschrijving, no. 32.

${ }^{55}$ Rembrandt, Company of Frans Banninck Cocq and Lieutenant Willem van Ruytenburch (known as The Nightwatch), 1642, Rijksmuseum, Amsterdam, inv.no. SK-C-5, on loan from the city of Amsterdam (SA 7392); Van Dyk, Kunst, no. 27; Scheltema, Historische beschrijving, no. 98; 
Haverkamp-Begemann, Night Watch; Dudok van Heel, “'The Night Watch' and the Entry of Marie de'Medici."

${ }^{56}$ Nicolaes Eliasz Pickenoy, Company of Captain Jan Claesz van Vlooswijck and Lieutenant Gerrit Hudde, 1642, Rijksmuseum, Amsterdam, inv.no. SK-C-1177, on loan from the city of Amsterdam (SA 7311); Van Dyk, Kunst, no. 53 (as A. Backer); Scheltema, Historische beschrijving, no. 4 (as A. Backer); The ensign on the portrait has been identified as Jan Witsen by ' $t$ Hart 1959. See also Van Gent 2012, p. 452.

${ }^{57}$ Jacob Backer, Company of Captain Cornelis de Graeff and Lieutenant Hendrick Lauwrensz, 1642, Rijksmuseum, Amsterdam, inv. no. SK-C-1174, on loan from the city of Amsterdam (SA 7284); Van Dyk, Kunst, no. 28 (as Jacob Backer); Scheltema, Historische beschrijving, no. 8 (as Jacob Backer); Wilhelm Martin, “Backer’s Korporaalschap uit den Kloveniersdoelen te Amsterdam," Oud Holland 50 (1933): 220-24, mentions a small copy, attributed to Lundens in a Berlin private collection.

${ }^{58}$ Bartholomeus van der Helst, Company of Captain Roelof Bicker and Lieutenant Jan Michielsz Blaeuw, 1639, Rijksmuseum, Amsterdam, inv.no. SK-C-375, on loan from the city of Amsterdam (SA 7327); Van Dyk, Kunst, no. 23; Scheltema, Historische beschrijving, no. 37. The painting was later replaced with Bartholomeus van der Helst, The Governors of the Kloveniersdoelen, 1655, Amsterdam Museum, inv. no. SA 2101, currently on loan to the National Gallery of Art, Washington, D.C., until March 2017; Van Dyk, Kunst, no. 44; Scheltema, Historische beschrijving, no. 39.

${ }^{59}$ Thomas de Keyser, Company of Captain Allaert Cloeck and Lieutenant Lucas Jacobsz Rotgans, 1632, Rijksmuseum, Amsterdam, inv. no. SK-C-381, on loan from the city of Amsterdam (SA 7353); Van Dyk, Kunst, no. 22; Scheltema, Historische beschrijving 1879, no. 56; Ann Jensen Adams, "Civic Guard Portraits: Private Interests and the Public Sphere," in Beeld en Zelfbeeld in de Nederlandse Kunst, 1550-1750 / Image and Self Image in Netherlandish Art, 1550-1750, ed. Reindert Falkenburg, Jan de Jong, Herman Roodenburg, and Frits Scholten, Nederlands Kunsthistorisch Jaarboek 46 (1995): 169-97.

${ }^{60}$ Nicolaes Eliasz Pickenoy, Company of Captain Dirck Tholinx and Lieutenant Pieter Adriaensz Raep (fragment), 1639, Amsterdam Museum, inv. no. SA 7314; Van Dyk,Kunst, no. 103; Scheltema, Historische beschrijving, no. 122.

${ }^{61}$ Circle of Pieter Pietersz, Company of Captain Pieter Dircksz Hasselaer and Lieutenant Jan Gerritsz Hooft (fragment), ca. 1595-1605, Amsterdam Museum, inv. no. SA 7388; Scheltema, Historische beschrijving, no. 119.

${ }^{62}$ Six and Del Court, "Schutterstukken," 77.

${ }^{63}$ Anonymous, Company of Captain Dirck Jacobsz Rosecrans and Lieutenant Ruysch, 1584, Amsterdam Museum, inv. no. SA 7351; Scheltema, Historische beschrijving 1879, no. 154 (as Ketel); Six and Del Court, "Schutterstukken," 77 (as Ketel).

${ }^{64}$ Van Dyk, Kunst, no. 8 (as Dirck Jacobsz); Scheltema, Historische beschrijving, no. 48 (as Dirck Jacobsz).

${ }^{65}$ Six and Del Court, "Schutterstukken," 77, 80 n. 1. Six and Del Court suggest that a copy after the lost painting by Backer can be found in the National Gallery, London (inv. no. 1343). Bauch argued against this idea in his monograph on Backer (Kurt Bauch, Jakob Adriaensz Backer: Ein Rembrandtschüler aus Friesland. (Berlin: G. Grote,1926), 100, claiming that it was probably a rejected sketch for Flinck's Company of Captain Joan Huydecoper and Lieutenant Frans van Waveren Celebrating the Treaty of Münster. No further research has been done on whether this was a copy after Backer's lost civic guard portrait. Mac Laren and Brown asserted that the copy was probably 
post-1850. (Neil MacLaren, The Dutch School, 1600-1900, revised and expanded by Christopher Brown [London: National Gallery, 1991], 125, pl. 108.) That, however, would not exclude its being a copy after the civic guard portrait, for the general composition of the London painting does resemble the Company of Captain Cornelis de Graeff and Lieutenant Hendrick Lauwrensz of 1642. Moreover, the street scene in the London painting loosely recalls the environment around the Kloveniersdoelen in that period.

${ }^{66}$ Van Dyk, Kunst, no. 6.

${ }^{67}$ Master of the Antwerp Family Portrait, Civic Guardsmen of Squad F, 1557, Amsterdam Museum, inv. no. SA 7344; Scheltema, Historische beschrijving, no. 153.

${ }^{68}$ According to Jan Six, and up until 2012 this painting was identified with Aert Pietersz, Company of Captain Jan de Bisschop and Lieutenant Pieter Egbertsz Vinck, 1599, Amsterdam Museum, inv. no. A 7386; Scheltema, Historische beschrijving, no. 87 (as Aert Pietersz). Judith van Gent has demonstrated convincingly that this cannot be the case since the captain on the painting has to be Jan Cornelisz Witsen and that therefore the identification of the captain as de Bisschop cannot be maintained. She concludes that the painting should actually be one of the 5 painting in the bastion" instead. Van Gent 2012, p. 454.

${ }^{69}$ Possibly Dirck Jacobsz, Company of the Kloveniersdoelen, 1532, Hermitage, St. Petersburg. Six and Del Court suggest another possibility: this is the portrait by Cornelis Ketel that Van Mander mentions in his Schilderboeck. Van Mander, Schilderboek, f. 275: "In t' jaer 1581 vertrack hy uyt Enghelandt nae Hollandt, en quam woonen t' Amsterdam, daer hem veel voor quam te conterfeyten nae t' leven. Onder ander, een corporaelschap van schutters leverde hy op de Cleuveniers doelen, waer van Capiteyn was Harman Rodenborgh Beths, daer hy sich selven oock in conterfeytte in profijl" (In the year 1581 he left England for Holland and went to live in Amsterdam where he obtained many portrait commissions - among others a corporalship of militia which he produced for the Kloveniersdoelen, of which the captain was Harman Rodenborgh Beths and in which he also portrayed himself in profile). Translation from The Lives of the Illustrious Netherlandish and German Painters (see note 22 above) 1:358.See Six and Del Court, "Schutterstukken," 76; (possibly) Van Dyk, Kunst, no. 10 (as Cornelis Ketel).

${ }^{70}$ Pieter Isaacsz, Company of Captain Jacob Gerrits. Hoing and Lieutenant Wybrand Appelman, 1596, Amsterdam Museum, inv. no. SA 7338; Scheltema, Historische beschrijving, no. 134.

${ }^{71}$ Master of the Antwerp Family Portrait, Civic Guardsmen of Squad B, 1556, Amsterdam Museum, inv. no. SA 7343; Scheltema, Historische beschrijving, no. 30 (as Jacob Cornelisz).

${ }^{72}$ Cornelis Anthonisz, Squad A of the Kloveniersdoelen, 1531, Amsterdam Museum, inv. no. SA 7278; Scheltema, Historische beschrijving, no. 133 (as Jan van Scorel).

${ }^{73}$ Cornelis van der Voort, Company of Captain Jonas Cornelisz Witsen and Lieutenant Volckert Overlander, ca. 1612-14, Amsterdam Museum, inv. no. SA 7433; Van Dyk, Kunst, no. 58 (as Moreelse, still in the Kloveniersdoelen); Scheltema, Historische beschrijving, no. 124. There is a copy of this painting in the Frans Banning Cock Album. 't Hart 1952; Van Gent 2012, p. 453. ${ }^{74}$ Paulus Moreelse, Company of Captain Jacob Hoynck and Lieutenant Nanning Cloeck, 1616, Rijksmuseum, Amsterdam, inv. no. SK-C-623, on loan from the city of Amsterdam (SA 7373); Van Dyk,Kunst, no. 58 (still in the Kloveniersdoelen); Scheltema, Historische beschrijving, no. 123; Six and Del Court, "Schutterstukken," 77.

${ }^{75}$ Scheltema, Historische beschrijving, no. 77 (as Paulus Moreelse).

${ }^{76}$ Possibly Cornelis van der Voort, Company of Eleven Civic Guardsmen, ca. 1610-30, Amsterdam Museum, inv. no. SA 7434; Van Dyk, Kunst, no. 26, Scheltema, Historische beschrijving, no. 130 
${ }^{77}$ Six and Del Court, "Schutterstukken," 76-77. The portrait of Jacob Schaep Pietersz in this "old piece" has possibly been the source of the copy of Portraits and Genealogy of the Ancestors of Gerrit Pietersz Schaep, Amsterdam Museum, inv. no. SB 2560, on loan from the Backer Stichting (fig.2 in Tom van der Molen, Introductionto the Translation of D. C. Meijer, Jr., "The Amsterdam Civic Guard Portraits within and outside the New Rijksmuseum," JHNA 5:1).

${ }^{78}$ Possibly Dirck Jacobsz, Company of the Klovenierdoelen, 1532, Hermitage, St. Petersburg, inv.no. 414; Six and Del Court, "Schutterstukken," 76.

${ }^{79}$ Possibly Dirck Jacobsz, Company of the Kloveniersdoelen, 1532, Hermitage, St. Petersburg, inv. no. 414; Six and Del Court, "Schutterstukken," 76.

${ }^{80}$ The portraits are no longer joined together. The two portraits are Dirk Jacobsz, Twelve Civic Guardsmen of Squad E, 1561, Hermitage, St. Petersburg, inv.no. 416; Jan Six, "Dirk Jacobsz.: Twee Amsterdamsche Schutterstukken te St. Petersburg," Oud Holland 13 (1895): 91-111; Six and Del Court, "Schutterstukken," 76; and Dirk Jacobsz, Twelve Civic Guardsmen of Squad E, 1563, Amsterdam Museum, inv. no. SA 7342; Scheltema, Historische beschrijving, no. 49.

${ }^{81}$ Dirck Barendsz, Meal of Eighteen Amsterdam Civic Guardsmen (known as"de poseters" [the ruffe-or perch eaters]), 1566, Rijksmuseum, Amsterdam, inv. no. SK-C-365, on loan from the city of Amsterdam (SA 7288); Van Mander, Schilderboeck, f. 259v: "Voorts op de Cluyveniers Doelen een Rot, daer sy ter Tafel sitten, en eten een gedaent van visch, die in Hollant wort Pors genoemt (Then in the Kloveniersdoelen a company where they sit at a table and eat a type of fish called pos in Holland). Translation from The Lives of the Illustrious Netherlandish and German Painters (see note 22 above), 1:297. See Van Dyk, Kunst, no. 9; Scheltema, Historische beschrijving, no. 12.

${ }^{82}$ Anonymous, Meal of Eight Civic Guardsmen, ca. 1550-60, Amsterdam Museum, inv. no. SA 7305; Scheltema, Historische beschrijving, no. 120.

${ }^{83}$ Allart Claesz, Squad of the Kloveniersdoelen, with Two Shooting Kings, 1534, Amsterdam Museum, inv. no. SA 7300; Van Dyk, Kunst, no. 6; Scheltema, Historische beschrijving, no. 13 (as Barendsz.).

${ }^{84}$ Dirck Jacobsz, Company of Civic Guardsmen in Three Parts, 1529-56, Amsterdam Museum, inv. no. SA 7341; Scheltema, Historische beschrijving, no. 117.

\section{Recommended citation:}

Tom van der Molen, translator, "The Paintings in the Three Civic Guard Halls in Amsterdam, Written by G. Schaep, 1653", JHNA 5:1 (Winter 2013) D0l:10.5092/jhna.2013.5.1.7 